\title{
sciendo
}

\section{New marine IBAs for the Mediterranean Shag Phalacrocorax aristotelis desmarestii IN SLOVENIA}

\section{Nova morska območja IBA za sredozemskega vranjeka Phalacrocorax aristotelis desmarestii v Sloveniji}

URŠKa Koce, DOPPS - BirdLife Slovenia, Tržaška cesta 2, 1000 Ljubljana, e-mail: ursa.koce@dopps.si

The IBA network is being regularly updated, based on new data and their better quality. There have been three previous stages of the marine IBA identification in Slovenia and the Mediterranean Shag has been included as the qualifying species only in the most recent stage in 2011 . However, the sites were limited to inshore coastal roost-sites and thus insufficient to cover the foraging areas of the species. To fill this gap in the Slovenian territorial sea, new marine IBAs have been identified for the Mediterranean Shag within the scope of the SIMARINE-NATURA (LIFE10NAT/SI/141) project in the 2011-2015 period. The new sites were identified following standardized methodology for the identification of marine IBAs from BirdLife International. The data on the Mediterranean Shag distribution and population size were collected using four field methods: (1) monthly monitoring at in-shore communal roost-sites, (2) monthly monitoring at sea following the standardized ESAS method, (3) GPS telemetry, and (4) unsystematic census of in-shore floating groups. Based on these data, one new site, the IBA Osrednji Tržaški zaliv, and one extension to the existing IBA Debeli rtič were identified, covering 8,218 ha and 155 ha, respectively. The new sites cover $39.2 \%$ of the Slovenian territorial sea.

\section{Introduction}

\subsection{Marine IBAs in Slovenia}

Conservation of marine biodiversity is widely implemented through IBA programme - Important Bird and Biodiversity Areas, established by BirdLife International. The main objectives of the programme are identification, protection and management of worldwide network of sites of crucial importance for the long-term conservation of wild bird populations (BIRDLIFE InTERNATIONAL 2010c). In contrast to the birds of the terrestrial environment, the seabird populations were poorly assessed until recently due to difficult access to the ornithological data in the marine environment, and this was reflected in a low number of identified marine IBAs, especially in off-shore areas; however, the number of BirdLife partners (corre- sponding to number of countries) involved in marine IBA identification and protection increased to over 40 by 2010 (BIRDLIFE INTERNATIONAL 2010a, c).

The IBA network is being updated regularly based on new data and their better quality. There have been three previous stages of IBA identification in Slovenia involving seabirds, however, the resulting marine IBA and Natura 2000 network has been assessed as insufficient by BirdLife International (BIRDLIFE INTERNATIONAL 2014). Common characteristic of previous marine IBA identification is that it was part of the pan-national IBA identification and / or revisions, focused on terrestrial sites (Božıč 2003, Denac et al. 2011, Polak 2000). Within these stages, four marine IBAs covering six species of seabirds were identified in the 2000-2011 period (Ibid.) The fourth (and most recent) stage of marine IBA identification in Slovenia, presented in this work, 
was implemented in the years 2011-2015 as part of the project SIMARINE-NATURA (LIFE10NAT/ SI/141) (www.simarine-natura.ptice.si). Contrary to previous stages when seabird censuses were limited to coastal and inshore areas, the monitoring of target species, i.e. the Mediterranean Shag Phalacrocorax aristotelis desmarestii, was conducted systematically across the entire range of the Slovenian territorial sea.

\subsection{Target species}

The Mediterranean Shag belongs to the cormorant family (Phalacrocoracidae). It is distributed solely in the Mediterranean and the Black Sea. Their entire breeding population is estimated at 8,700-11,130 pairs, breeding in over 400 colonies (BAZIN \& IMBERT 2012). The largest national breeding numbers are found in Croatia, Italy, Greece and France, ranging from 1,000 to 2,000 pairs (BAZIN \& IMBERT 2012). The total nonbreeding population of the Mediterranean Shags is estimated at 30,000 individuals (WETLANDS INTERNATIONAL 2004). In the post-breeding season, part of the population spreads out of their breeding area, to the non-breeding areas up to several hundred kilometres from their breeding colonies (ŠKORNIK et al. 2011). The majority of the Adriatic population, almost entirely breeding in Croatian waters, migrates to the Gulf of Venezia (SPONZA et al. 2013). In summer and autumn, only the Gulf of Trieste hosts around 6,000 and exceptionally even up to 10,000 individuals (ŠKORNIK et al. 2011), representing 20-33\% of the total non-breeding population (WETLANDS INTERNATIONAL 2004). The roosting population along the Slovenian coast was estimated at 2,000 3,000 individuals in the 2006-2011 period (DENAC et al. 2011). Regular seasonal migration from the Croatian breeding areas to the Gulf of Trieste was established fairly recently, in the 1980s, and became massive at the end of the 1990s (Š́KORNIK et al. 2011). The onset of post-breeding migration to the north coincides with the period of extensive overfishing in the Croatian waters and could be triggered by the lack of food around the breeding colonies and facilitated by high foraging efficiency in the shallow Gulf of Trieste, abundant with easy accessible fish prey (SPONZA et al. 2010). Moreover, the increase in the numbers of the Mediterranean
Shags in the Gulf of Trieste coincides also with the swing of shellfish farming on filamentous floating farms that enable the shags' undisturbed roosting on otherwise highly populated coast of the Gulf. There are three such communal roost-sites along the Slovenian coast, near Debeli rtič, Strunjan and Sečoveljske soline (Bordjan et al. 2013, Koce \& LIPEJ 2016). All sites have already been identified as marine IBAs and included in the Natura 2000 network (DenaC et al. 2011, Koce \& Lipej 2016).

The Mediterranean Shags forage predominantly on fish (BAzIN \& IMBERT 2012, Cosolo et al. 2011, LiPEj et al. 2016). They are foot propelled pursuit-divers, usually preying near sea-bed, but occasionally also in pelagic waters, especially in shallow coastal belt (BAZIN \& IMBERT 2012). Their foraging dives are regularly $30 \mathrm{~m}$ deep, often up to $60 \mathrm{~m}$ and in extreme cases even up to $80 \mathrm{~m}$ (BAZIN \& IMBERT 2012) and can last over one minute (SPONZA et al. 2010). They usually forage solitarily or in small groups independently from one another, but they also socialize in large groups of up to few hundred individuals and communally prey on schools of small pelagic fish in coastal shoals (NELSON 2005), sometimes in the company of other seabird species, e.g. the Black-headed Gulls Chroicocephalus ridibundus (pers. observation). This is a common phenomenon in the marine environment known as multi species foraging groups (CAMPhuYsen \& GarThe 2004).

The Mediterranean Shag is a dietary opportunist preying on the commonest and most easily accessible prey in the benthic zone. The majority of its prey in the Adriatic sea represent economically unimportant fish species: around the Croatian breeding sites (Oruda Island), the diet consisted predominantly of big-scale sand smelt Atherina boyeri, brown comber Seranus hepatus and peacock wrasse Crenilabrus tinca, however, in the Gulf of Trieste their main food is black goby Gobius niger (Cosolo et al. 2011, LIPEJ et al. 2016).

As a species, the European Shag (Phalacrocorax aristotelis) is not endangered by the IUCN criteria and has a favourable conservation status at the European level (non-SPEC) (BIRDLIFE INTERNATIONAL 2004). The status assessment after SPEC classification for the Mediterranean subspecies was not made. Although historical population estimates for the Mediterranean Shag are rather poor, the experts 
agree that its population has decreased (AgUILAR \& FERnÁndeZ 2002). Due to the limited range and small population, the Mediterranean Shag is listed on the Annex I of the Bird Directive, Annex II of the Bern Convention and on the list of priority species of the Barcelona Convention.

\section{Methods}

\subsection{Target geographic area}

Within the scope of the SIMARINE-NATURA project (2011-2016), the target geographic area for the identification of marine IBAs was defined as part of the then-claimed Slovenian territorial sea within the Gulf of Trieste (hereafter referred to as 'project area'). The project area was selected based on previous data on importance of the Gulf of Trieste for the post-breeding population of the Mediterranean Shags (VREzec 2006b). However, the Slovenian territorial sea was redefined in 2017 as a result of the arbitration between Slovenia and Croatia. As the present Slovenian territorial sea overlaps very well with the project area it represents the target geographic area in this work (Figure 1). Surface area of the target area, i.e. the Slovenian territorial sea, is $214 \mathrm{~km}^{2}$. Surface area of the project area is $211 \mathrm{~km}^{2}$.

\subsection{Marine IBA identification methodology}

The identification of marine IBAs in the Slovenian territorial sea was conducted following the protocol proposed by BIRDLIFE INTERNATIONAL (2010b). The protocol recommends nine analytical steps: (1) identification of target species; (2) seabird and environmental data gathering from all possible sources, including systematic surveys, existing databases, reports and published work; (3) spatial data analysis resulting in GIS layers based on different data sources, species by species and organization of data for comparison between different months/seasons/ years; (4) classification of data layers based on data quality to primary and supplementary; (5) identification of candidate sites for each seabird species; (6) application of standard IBA criteria and confirmation that the IBA candidates sites comply with the criteria; (7) delineation of final boundaries. Steps 5 and 7 were merged in our study because only one target species was defined. The IBA proposals with the descriptions are entered into the "World Birds and Biodiversity Database" (WBDB) managed by BirdLife International (https://www.globalconservation.info/). As the final step, the BirdLife Secretariat reviews the proposals and decides about the confirmation of proposed IBAs.

\subsubsection{Identification of target species}

According to BirdLife International (2010b), about 340 extant species are categorized as seabirds and theoretically all of them are suitable for the analysis in the process of the marine IBA identification. However, for practical reasons it is recommended that one or some priority species are defined based on their conservation status, data availability, and expected distribution at sea, etc. (BirdLife International 2010b). In Slovenia, 42 seabirds have been recorded in coastal and marine environment since 1950 (KoCE \& LIPEJ 2016), six of which met the criteria for either identification of new IBAs or inclusion in the existing IBAs in previous stages of the IBA identification (BožIČ 2003, DENAC et al. 2011, Koce \& Lipej 2016, PolaK 2000). In opposition to previous stages when the identification of marine IBAs was limited to coastal and inshore areas and was focused on breeding colonies and communal roost-sites, the focus in the present stage was an identification of offshore marine IBAs with emphasis on species' foraging areas. Considering these recommendations from BirdLife InTERnational (2010b), the Mediterranean Shag was selected as the only target species, based on the following characteristics: (1) it is listed in the Annex I of the Birds Directive, Annex II of the Bern Convention and among priority species of the Barcelona Convention, (2) it has a negative population trend in a geographically limited range (BAZIN \& IMBERT 2012), (3) it has a relatively large population in the target area (VREZEC 2006a), (4) it has expected concentrations rather than extremely dispersed distribution at offshore sea (VREZEC 2006b), (5) it qualifies as an umbrella species in the target marine environment (Koce \& Lipej 2016). Other seabird species occurring at Slovenian sea at present failed to meet one or more of these 


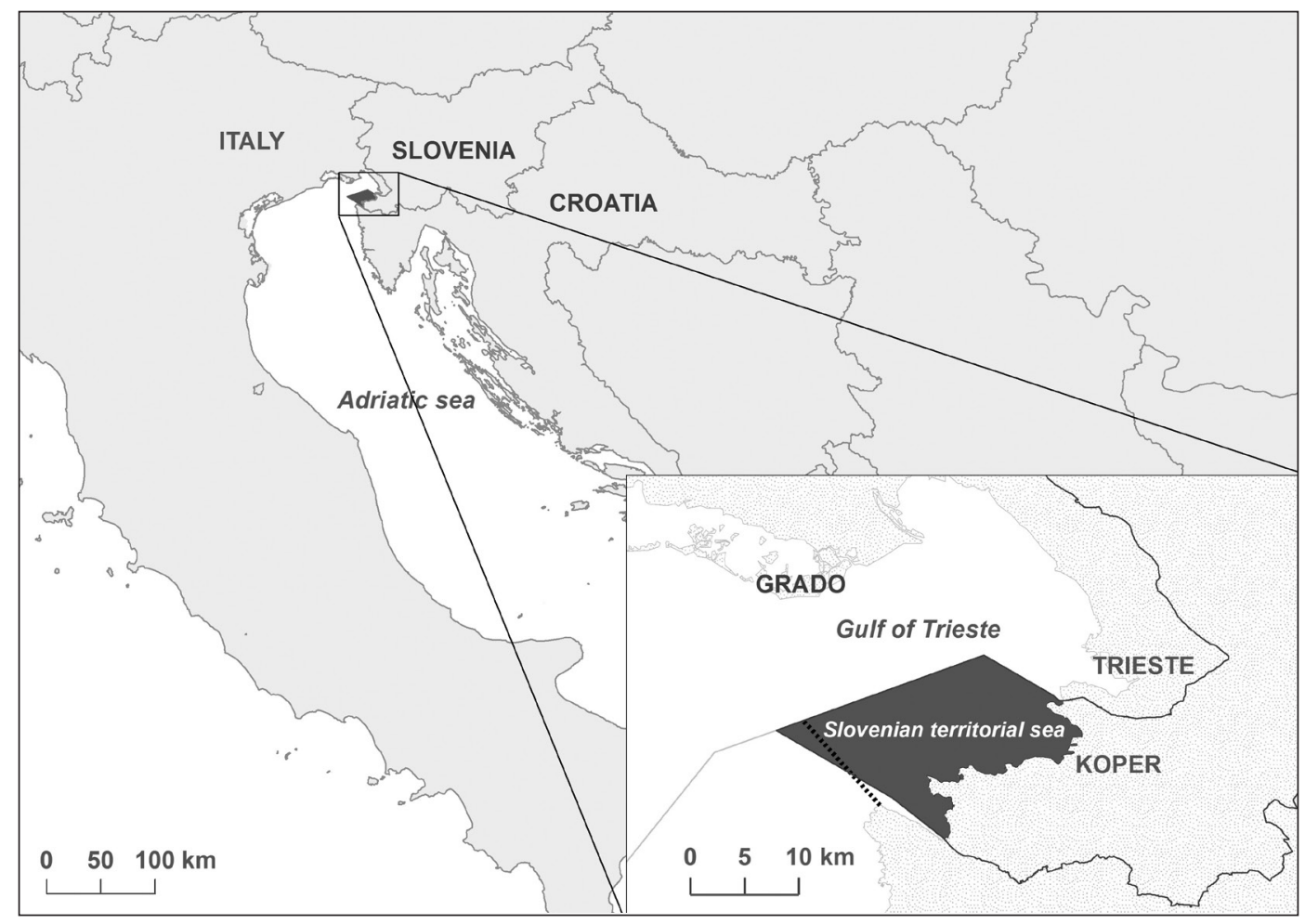

Figure 1. Target geographic area (Slovenian territorial sea) for the identification of marine IBAs for the Mediterranean Shag (Phalacrocorax aristotelis desmarestii). Black dashed line on the bottom map denotes the non-overlapping part of the project area border as defined in the SIMARINE-NATURA (LIFE1ONAT/SI/141) project.

criteria and were thus not selected as priority species for the identification of marine IBAs in this stage. Moreover, the Mediterranean Shag was a priority species for financing by LIFE, the EU financial instrument supporting the conservation projects for Natura 2000 qualifying species that enhanced the marine IBA identification process in the 2007-2013 programming period, including through the SIMARINE-NATURA project.

\subsubsection{Data gathering}

The data on the Mediterranean Shag distribution and population size were collected in the years 2011-2014, using four field methods: (1) monthly monitoring at in-shore communal roost-sites, (2) monthly monitoring at sea following standardized ESAS method, (3) GPS telemetry, and (4) unsystematic census of in-shore foraging groups.

\subsubsection{Monitoring at communal roost-sites}

Monitoring of roosting individuals was conducted to assess the size and temporal dynamics of the roosting population in the Slovenian sea. The monitoring was conducted between November 2011 and October 2013 at three inshore locations previously known as their main communal roost-sites along the Slovenian coast. They are situated on floating infrastructure (buoys) of shellfish farms, located in the Bay of St. Bartholomeus (Zaliv Sv. Jerneja), Strunjan Bay (Strunjanski zaliv) and Piran Bay (Piranski zaliv). The sites had been previously identified as marine IBAs Debeli rtič, Strunjan and Sečoveljske soline, respectively (Denac et al. 2011). The censuses of shags at the roost-sites were conducted once a month, synchronously at all three locations. Counts on one census occasion were done every half an 
hour, starting two hours before sunset and ending at the time when light conditions were too poor to continue counting. The shags were classified by age in two classes: adults and non-adults (juveniles and sub-adults). All shags within the area of a roost-site were counted, including individuals swimming in the sea among buoys, because most of them stayed within the roost-site and occupied buoys within short period of time. The roost-site in the Bay of St. Bartholomeus is divided by national border with Italy in two parts but the shags were counted on both sides of the border as the location is functionally one roost-site. Based on the results of the roost-site monitoring, the peak non-breeding season was defined as the period when the total number of individuals was higher than mid-range, calculated as $0.5 \times\left(\mathrm{n}_{\max }+\mathrm{n}_{\min }\right)$ (i.e. 763 individuals).

\subsubsection{Monitoring at sea following ESAS method}

Monitoring at sea was done every month between July 2012 and August 2013 following the standardized ESAS method ('European Seabirds At Sea'), whereby the birds were counted along line-transect, using boat (CAMPHUYSEN \& GARTHE 2004).

The transect line in this survey was placed on the project area in a pattern that ensured representativeness for the area (Figure 2). It covered an entire gradient of distances from the coast to the outer border of the territorial sea as well as longitude gradient. The total length of the transect line corresponded to the distance travelled by the survey boat in $4-5$ hours $(81.6 \mathrm{~km})$, corresponding to the time available for an optimal at-sea census of the Mediterranean Shags in one day. The censuses were conducted during the diurnal period when most shags were expected to be active outside their roost-sites.

The boat was travelling at constant speed of 10 knots. The birds were recorded within 5 minute intervals. Given constant speed of 10 knots, this corresponds to segments of length $1,540 \mathrm{~m}$. In case the boat changed its direction or speed, an ongoing census interval was aborted and a new interval started at the location of the change. The birds were recorded on both sides of the transect line in two bands: $300 \mathrm{~m}$ inner band and an unlimited outer band. The instant counting area was limited to a distance of $300 \mathrm{~m}$ in front of the boat. The distance was estimated by the rule of thumb by each observer upon prior calibration at a measured distance $300 \mathrm{~m}$ from the coast. The birds which were in contact with water were counted continuously, whereas the flying birds were counted in snapshots in one minute intervals. The birds were detected with a naked eye; binoculars were used only for the identification of individual's age class, whereby two classes were defined based on their plumage: nonadults and adults.

The data were entered in a standardized ESAS monitoring form. The following types of data were recorded: (1) census metadata (date, boat name and type, names of observers, type of census, group of recorded birds), (2) data about census interval (geographic coordinates of the starting point, interval start and end time, sea state on the Beaufort scale, visibility, floating objects and matter), and (3) interval specific bird data (age class, transect band, number of individuals, movement direction, association with objects or non-avian species, behaviour, prey, multi-species group membership).

\subsubsection{GPS telemetry}

The shags were being trapped in autumn 2012 and in summers 2013-2014. Self-made clap-traps with remote triggering system were used. The traps were adapted for mounting on three different floating objects: vertical cylindrical buoys $(\mathrm{r}=1 \mathrm{~m})$, cubic rafts $(\mathrm{a}=1 \mathrm{~m})$ and horizontal cylindrical buoys $(\mathrm{r}=0.4 \mathrm{~m})$. The trap was triggered remotely by the user when one or more shags sat on the buoy or raft.

The traps were set at three sites along the Slovenian coast: (1) in Viližan Bay on the east side of the town of Izola and within two communal roost-sites of the Mediterranean Shags near Strunjan (2) and Sečovlje (3). At the Izola trapping site, the traps were mounted on four existing vertical cylindrical buoys, two at a time. At the Strunjan and Sečovlje trapping sites, two cubic self-made rafts were tied among the existing buoys of the shellfish farms where the shags usually rest, one at each site. In addition, three traps were set on the existing surrounding horizontal cylindrical buoys at the Strunjan trapping site.

We tagged the shags with GPS-GSM loggers of Polish producer ECOTONE. Three units of DUCK-3 model and 26 units of SAKER model were used. 16 units of the SAKER model were filled with polyurethane and 10 units with resin. 
The dimensions of the DUCK-3 model were $45 \times 25 \times 25 \mathrm{~mm}$, weight $=40 \mathrm{~g}$, and those of the SAKER model were $45 \times 25 \times 18 \mathrm{~mm}$, weight $=25$ (series with polyurethane filling) or $40 \mathrm{~g}$ (series with resin filling). The devices were mounted on birds permanently, as backpacks with teflon ribbon straps.

The devices were supplied with energy through solar panels, which provided enough energy in good light conditions to fix a GPS position every half an hour. The data were transferred to server by SMSs after every 4 GPS fixes. They were accessible to the user by the Internet through a password protected web panel. Frequency and accuracy of GPS fixes, and operating hours of the loggers could be set remotely via the web panel. We tended to set the highest frequency of fixes during the day but sometimes it needed to be lowered due to low natural light levels and consequent need for energy savings. The loggers were switched off during the mid-night hours.

\subsubsection{Land-based census of large floating groups}

In the years 2011-2014, the data on large floating groups of the Mediterranean Shags ( $\geq 10$ individuals) were collected unsystematically based on participation of experienced volunteer observers. The data were reported by observers through online web form (http://simarine-natura.ptice.si/sodeluj/). To enhance the census effort, the public was also called to participate in data collection through different means of communication: DOPPS - BirdLife Facebook page, SIMARINE-NATURA project website, leaflets and newspaper articles as well as personal communication.

\subsubsection{Production of basic spatial data layers and ecological models}

\subsubsection{ESAS dataset}

Filtering of the ESAS data. The aim of the analysis was to identify the areas important for foraging shags, hence we omitted the following data from the original ESAS dataset: flying individuals, as the shags never predate from the air, and the individuals resting along the shore or floating objects at sea. The individuals which were not observed during their foraging activity but were swimming in the sea were retained in the dataset, assuming that they have most likely been foraging at or near the locations where observed, based on the information from the literature and results of the GPS telemetry analysis in this study. According to NeLson (2005), the breeding shags fly directly to their foraging area and return to the colony in the same manner. According to the results of the GPS telemetry survey in this study this holds also in case of non-breeding shags that take foraging trips from communal roost-sites. We refer to the resulting dataset as 'ESAS data subset 1'. Furthermore, we omitted the individuals which were associated with large $(>12 \mathrm{~m})$ fishing boats, assuming that they were momentarily foraging on the discards and were thus not associated with their usual foraging habitat, i.e. marine benthos. We refer to the resulting dataset as 'ESAS data subset 2'.

Calculation of shag densities. The densities of shags were calculated at the level of transect and at the level of transect segments (intervals) based on the number of individuals registered in the inner $300 \mathrm{~m}$ band. They were calculated separately for each census occasion (denoted by date) and from each of the two ESAS data subsets.

Furthermore, a raster layer of mean densities in the peak non-breeding season at the transect was produced in ArcGIS 10.3 (ESRI 2014) with 'Polyline to Raster' tool, based on each of the two ESAS data subsets. Linear vector layers consisting of transect segments with shag density as an attribute were used as input data. Rasterization was conducted separately for each census conducted in peak nonbreeding season. The final raster layer with mean densities was made using 'Cell Statistics' tool, using census-specific raster layers as input data.

Production of ecological models of the Mediterranean Shag distribution: To explain the distribution of the foraging Mediterranean Shags in the Slovenian territorial sea in peak non-breeding season, the number of shags in transect segments was modelled as a function of several ecological variables (Table 1). Two sets of models were fit each based on one of the ESAS data subsets $(1,2)$, whereby only the censuses from peak non-breeding season were included. The modelling was done in R (R Development Core Team 2018) using packages 'MASS' and 'mgcv' (Venables \& Ripley 2002, Wood 2004). GAMM models with negative binomial distribution of the response variable (number 
of shags in transect segment) were fit, following ZUUR et al. 2009. Logarithmically transformed surface area of a transect segment was included in the models as an offset variable due to differing length of the transect segments. The potential effects of pseudo-replication due to repeated censuses at the same transect were taken into account with the inclusion of 'census date' random variable. The ecological data represented by a set of fixed variables were obtained from GIS layers at the intersections with central points of the transect segments, or recorded at sea during census (Table 1). The variable 'sea depth' was eliminated from further analysis because it was in strong correlation with the variable 'distance from the coast' (Pearson's correlation coefficient $=0.7)$. The decision to eliminate the former instead the latter was based on the facts that (1) the bathymetry of the Slovenian sea is more or less uniform and most of the sea bottom belongs to the same depth class (20-30 m), (2) the depth of the sea in the area is not a limiting factor for the shags. The variables describing the presence of fishing boats were included only in the models which were fit based on ESAS data subset 1 . The best model in each set was selected based on AIC (Akaike information criterion) (BURNHAM \& ANDERSON 2002)

\subsubsection{GPS telemetry dataset}

Filtering of the GPS data. The original dataset was cleared before it was used for the analysis. In this step the following GPS locations were omitted from the dataset: locations which were fixed (1) before the shag was released, (2) after the shag died, was suspected to be dead or severely injured, (3) when the shag was apparently on migration or at breeding site, and (4) locations with an obvious error (i.e. more than $100 \mathrm{~m}$ inland). The outcome data subset in this step is referred to as 'clear dataset'. Moreover, the GPS locations in the 'clear dataset' were grouped by a date-individual grouping variable (i.e. GPS locations from one individual fixed in the same day were assigned unique and equal group number). Furthermore, the locations were classified into three daily periods according to the fixing time: (1) day, (2) twilight and (3) night, based on astronomical data about time of sunrise, sunset and beginning or end of nautical twilight in Ljubljana, Slovenia (http://www.timeanddate.com/sun/slovenia/ ljubljana). Furthermore, GPS locations of five shags which were tracked for less than three days were excluded from the analysis at this point.

Identification of roost-sites along the Slovenian coast. Besides the three traditionally known main communal roost-sites on shellfish farms, the shags were suspected to regularly roost at several other locations along the Slovenian coast. These regularly used roost-sites were identified based on clusters of roosting locations of the tracked individuals. A roosting location of an individual shag was defined as the first fixed GPS location in a day (usually early in the morning before the shags leave their roost-sites). Roost-sites were then defined as clusters of at least five roosting locations not further than $500 \mathrm{~m}$ from one another

Table 1. Independent variables used in the modelling of the Mediterranean Shag Phalacrocorax aristotelis desmarestii distribution in the Slovenian territorial sea

\begin{tabular}{lrrr}
\hline Independent variable & Variable type & Level & Data source \\
\hline $\begin{array}{l}\text { census date } \\
\text { presence of small fishing boats (up to } 12 \mathrm{~m} \text { ) }\end{array}$ & date & census & ESAS dataset \\
$\begin{array}{l}\text { presence of large fishing boats (above } 12 \mathrm{~m} \text { ) } \\
<0,5 \mathrm{~km} \text { away }\end{array}$ & binary & transect segment & ESAS dataset \\
$\begin{array}{l}\text { presence of large fishing boats (above } 12 \mathrm{~m}) \\
0,5-2 \mathrm{~km} \text { away }\end{array}$ & binary & transect segment & ESAS dataset \\
sea state (Beaufort scale) & factorial & transect segment & ESAS dataset \\
sediment type & factorial & transect segment & $\begin{array}{r}\text { GIS layer (Geodetski } \\
\text { inštitut Slovenije) }\end{array}$ \\
distance from the coast & continuous & transect segment & calculated in ArcGIS \\
\hline
\end{tabular}


and delineated as minimal convex polygons. Only roost-sites along the Slovenian coast were taken into account and roosting events in the Italian and Croatian territorial sea were excluded from further analysis. A centre of each roost-site was defined as the mean mid-point of the cluster, which was used in the following steps of the analysis (referred to as a roost-site centre from hereon).

Further filtering of the data. In this step, only those locations were retained in the dataset that belonged to individual shags roosting at the three main communal roost-sites and roost-sites identified during the previous step. Furthermore, in order to focus on the areas where the shags have been most likely foraging and not only resting, more locations were omitted: (1) diurnal locations within roost-sites, (2) GPS locations at other daytime resting places, or (3) artificial feeding locations (i.e. locations next to the fish market where at least two tagged shags have been known to be fed by fish sellers), (4) night and twilight locations outside roost-sites (probably erroneous fixes). We refer to the resulting data subset as 'end dataset'. It was used during the following steps as an input dataset for the delineation of the marine IBA candidates.

\subsubsection{Large floating groups dataset}

The data were digitalized in ArcGIS 10.3 (ESRI 2014) and the groups distinguished according to their foraging activity at the time of observation to foraging and non-foraging.

\subsubsection{Classification of spatial data layers}

The spatial data layers were classified as primary or supplementary based on their quality, following the recommendations by BIRDLIFE INTERNATIONAL (2010b).

\subsubsection{Identification of marine IBA candidates by spatial data layers}

\subsubsection{ESAS dataset}

Selection of $5 \%$ transect segments with the highest densities. Identification of the marine IBA candidate was based on the densities of shags at transect segments, calculated from both ESAS subsets. Only the peak-nonbreeding season of the Mediterranean Shags was considered, as revealed by the results of the roost-sites monitoring (Table 2). Following the recommendations by BIRDLIFE INTERNATIONAL (2010b), 5\% of transect segments with highest densities of shags were chosen for each census occasion (referred to as the best segments from hereon), separately for each ESAS subset $(1,2)$.

Selection of grid cells intersected by best transect segments. The target area was then overlaid with a grid of cells with side size $1,540 \mathrm{~m}$ (corresponding to the length of one standard transect segment, rounded to $10 \mathrm{~m}$ ). The cells which were intersected by the segments identified during the previous step were selected from the grid. The selected cells were used as a basic framework for the delineation of the marine IBA candidate.

\subsubsection{GPS telemetry dataset}

The marine IBA candidates were identified following BirdLife International's protocol for the identification of marine IBAs using seabird tracking data (BIRdLIFE INTERNATIONAL 2013). The protocol assumes central-place foraging, whereby an individual's roost-site was defined as the central place. The analytical method aims at the identification of core use areas (kernels) of tracked individuals on their round trips, taken from the roost-site to foraging areas and back to the roost-site (hereafter referred to as 'round foraging trips'). A core use area identified for a round foraging trip represents a foraging site of the individual shag making that trip.

The protocol consists of eight analytical steps. In step 1, the GPS data from the 'end dataset' were grouped by roost-sites. We thus obtained 10 subsets of 'end dataset', one for each roost-site, and from hereon we describe the method for analysing individual roost-site subsets. In step 2, each subset was further split to round foraging trips. A set of locations was considered to represent a trip when the shag moved at least a defined distance from the roost-site centre, stayed on its journey for at least 1 hour, and returned back to the same roost-site i.e. closer than a defined distance from the roost-site centre. The distances (referred to as inner and outer buffer) for each roost-site were defined according to the roost-site characteristics 
(Table 9). Furthermore, trips with less than six locations were automatically omitted from the analysis as they were below the numerical threshold for identification of core use areas. In step 3 the scale of interaction with the environment was calculated and further used in step 4 for fitting the kernels, i.e. identification of core use areas. In step 5 , a variance test was applied on the resulting set of kernels to check for significant site fidelity of any individual. In case site fidelity of one or more individuals was significant, only one randomly chosen core use area per individual was chosen for further analysis, to avoid bias due to pseudo replication. In step 6 , bootstrapping was used to assess the representativeness of the dataset and to calculate the percentage of the roosting population utilizing the marine IBA candidate. If the dataset was not representative (bootstrap outcome $<70 \%$ ), no IBA candidates could be identified. In step 7 , the areas more intensively used by several individuals (i.e. marine IBA candidates) were identified, and in step 8 threshold values were applied to these areas, estimated as \% of roosting population that visits each area. Steps $2-8$ were applied separately to each data group as defined in step 1 .

\subsubsection{Large floating groups dataset}

The marine IBA candidates were delineated based on a 1,000 $\mathrm{m}$ buffer around locations of the groups that were recorded at the time of active foraging. Additional criterion was used to include only the groups that were larger than the median group size, i.e. the threshold was set at minimum 130 individuals.

\subsubsection{Delineation of final marine IBA proposals}

The delineation of final marine IBA proposals was done based on integration of IBA candidates identified from different source data layers. The strength of each IBA proposal was evaluated against the rules outlined in BIRDLIFE INTERNATIONAL (2010b). According to these rules, the most defendable cases of marine IBAs are those identified based on two primary data layers, followed by the cases identified based on one primary and one supplementary data layer, and the cases identified based on one primary data layer. The cases identified based on two supplementary data layers are defendable only exceptionally, depending on the data involved, and the cases identified based on one supplementary data layer cannot be confirmed.

\subsubsection{Application of IBA criteria}

\subsubsection{Relevant IBA criteria}

BirdLife International lists 20 criteria for the identification of IBAs (http://datazone.birdlife.org/ site/ibacriteria), nine of which apply to the IBAs in the marine environment. The marine IBA proposals for the Mediterranean Shag in the Slovenian sea have been evaluated against three relevant criteria:

Blii. Congregations: The site is known or thought to hold $\geq 1 \%$ of a distinct population of a seabird species.

C2. Concentrations of a species threatened at the European Union level: The site is known to regularly hold at least $1 \%$ of a flyway population or of the EU population of a species threatened at the EU level (listed on Annex I and referred to in Article 4.1 of the EC Birds Directive).

C6. Species threatened at the European Union level: The site is one of the five most important in the European region (NUTS region) in question for a species or subspecies considered threatened in the European Union (i.e. listed in Annex I of the EC Birds Directive).

\subsubsection{Numerical thresholds}

Two of the relevant IBA criteria, B1ii and C2, prescribe a numerical threshold that needs to be reached in the proposed IBA, i.e. the site has to hold at least $1 \%$ of migratory or biogeographic population (http://datazone.birdlife.org/site/ ibacriteria). Based on the population estimates by WeTLANDS INTERNATIONAL (2004) for the non-breeding population of the Mediterranean Shag, this threshold is at 300 individuals. To check whether the numerical threshold has been reached in the marine IBA proposals, the number of individuals using the sites has been assessed for each proposal, using the data from different sources that were used for their delineation.

IBA Osrednji Tržaški zaliv. The number of individuals using the site was estimated based on 
(1) the extrapolation from transect densities and (2) model predictions.

In case of the extrapolation, the ESAS dataset 1 was used as input data, i.e. the number of all floating shags in the area was estimated. The number of individuals was calculated within the target area and within the marine IBA proposal, for each census occasion separately, by multiplying density of shags at the transect with the surface area of either site. In case of the IBA estimates, only the part of the transect overlapping the IBA was considered for the calculation of shags' density. To check whether the number of shags reached the numerical threshold required in IBA criteria C2 and Blii over two different years in at least one season, we tested whether the mean population estimates in the IBA proposal in meteorological summer (June to August) of both census years exceeded the threshold of 300 individuals, using one tailed Student t-test. The assumption of the test that the sample population size estimates need to be normally distributed was checked and confirmed with Shapiro-Wilcoxon test of normality ( $W=0.98, p=0.93$ ).

The model predictions were done based on a new dataset, represented by a grid of cells that was used for the delineation of the marine IBA candidate. The grid was clipped to exactly match the target area or the area of the IBA proposal, resulting in several partial grid cells at the edges. To account for the different cell surface areas, logarithmically transformed surface area of cells was calculated (i.e. representing the offset variable as used in the models). The values of the variable 'distance from the coast' were obtained in ArcGIS 10.3 (ESRI 2014) as the distance of the cell central point from the coastal line. To simulate the effect of fishing boats variable 'presence of large fishing boats $<0.5 \mathrm{~km}$ away' was set to "yes" in one randomly chosen cell, and variable 'presence of large fishing boats $0.5-2 \mathrm{~km}$ away' in two randomly chosen cells. The sea state was set to level zero to account for the optimal monitoring conditions. Any nonsignificant estimates were interpreted as not different from zero (i.e. the predictor has no effect). The mean predicted values and standard errors (SE) were calculated using 'predict.gam' function in $\mathrm{R}$ package 'mgcv' (Wood 2004), and 90\% confidence intervals were calculated by the equation: mean \pm $1,645 \times$ SE. All values were calculated on the scale of the linear predictor and then transformed to the scale of the response variable, i.e. the number of individuals present in a grid cell. The total number of individuals in the IBA proposal was calculated as a sum of individuals across the cells which intersect the area of the site.

Extension to IBA Debeli rtič. The number of birds visiting the area was assessed based on the census of large foraging groups and on the estimated number of individuals using the IBA candidate 1A, identified in the analysis of GPS telemetry data (Table 10).

\subsubsection{Regularity of use of the area}

Besides the fact that the numerical thresholds have been reached it needs to be demonstrated that the site is being regularly used by the target species. According to the BirdLife International protocol for the identification of marine IBAs this means that the birds are visiting the area in different periods (seasons or years) or that the area is visited by the birds from different sites (i.e. breeding colonies or roost-sites) (BirdLife InTERnational 2010b).

\section{Results}

\subsection{Monitoring at communal roost-sites}

Altogether, 24 monthly censuses were conducted at three communal roost-sites of the Mediterranean Shags between November 2011 and the end of October 2012 (Table 2). Their number peaked in August 2013 when 1,494 individuals were counted. The minimum was observed in March 2012 when only 32 individuals were counted.

\subsection{Monitoring at sea following the ESAS method}

Altogether, 16 censuses were conducted between July 2012 and August 2013 (Table 3). The length of a standard transect was $81.58 \mathrm{~km}$ and the width was $600 \mathrm{~m}$. The mean census time was 4:31. Two censuses (22.6.2012 and 21.5.2013) were not conducted entirely due to bad weather conditions and hence omitted from further analysis.

Densities of the Mediterranean Shags at the transect. The density of shags at the transect varied greatly between censuses (Table 14). The highest density at the transect was observed in July 2013 
when it reached 4.4 ind. $/ \mathrm{km}^{2}$ (all floating shags) or 3.4 ind. $/ \mathrm{km}^{2}$ (floating shags without those associated with fishing boats) (Table 14). The lowest densities were observed in January, February and March 2013 when less than 10 floating individuals were observed at the transect (Table 14). The mean density of shags in peak non-breeding season (data pooled for years 2012 and 2013) was generally higher off-shore than in-shore whether the shags associated with fishing boats were considered or not (Figure 2).

Ecological models of the Mediterranean Shag distribution. Altogether, seven (set 1) and five (set 2) models were fit to describe the distribution of the Mediterranean Shags in the Slovenian sea (Table 4). The selected, most parsimonious model in set 1 (M1.5) contained five fixed variables. Four of these variables had significant coefficients: the 'distance from the coast', 'presence of large fishing boats $<0.5 \mathrm{~km}$ away', 'presence of large fishing boats $0.5-2 \mathrm{~km}$ away' and the 'sea state'. All but the latter had positive effects on the number of shags in the transect segments (Table 5). The selected, most parsimonious model in set 2 (M2.5) contained two fixed variables, the 'distance from the coast' and

Table 2. The number of roosting Mediterranean Shags Phalacrocorax aristotelis desmarestii at three main communal roost-sites on shellfish farms along the Slovenian coast in 2011-2013; the difference between the total number of individuals (Total ind.) and the sum of adults (Ad.) and non-adults (Non-ad.) equals the number of individuals of unknown age. The shadowed censuses define the peak non-breeding season.

\begin{tabular}{|c|c|c|c|c|c|c|c|c|c|c|}
\hline \multirow[b]{2}{*}{ Date } & \multirow{2}{*}{$\begin{array}{l}\begin{array}{l}\text { All roost- } \\
\text { sites }\end{array} \\
\text { Total ind. } \\
\end{array}$} & \multicolumn{3}{|c|}{ Debeli rtič } & \multicolumn{3}{|c|}{ Strunjan } & \multicolumn{3}{|c|}{ Sečovlje } \\
\hline & & Ad. & $\begin{array}{l}\text { Non- } \\
\text { ad. }\end{array}$ & $\begin{array}{l}\text { Total } \\
\text { ind. }\end{array}$ & Ad. & $\begin{array}{l}\text { Non- } \\
\text { ad. }\end{array}$ & $\begin{array}{l}\text { Total } \\
\text { ind. }\end{array}$ & Ad. & $\begin{array}{l}\text { Non- } \\
\text { ad. }\end{array}$ & $\begin{array}{l}\text { Total } \\
\text { ind. }\end{array}$ \\
\hline 22.11 .2011 & 725 & & & 344 & & & 53 & & & 328 \\
\hline 21.12 .2011 & 485 & 141 & 32 & 173 & 10 & 34 & 44 & & & 268 \\
\hline 14.1 .2012 & 172 & 3 & 27 & 32 & & & 18 & & & 122 \\
\hline 16.2 .2012 & 90 & 6 & 14 & 22 & 0 & 46 & 46 & 7 & 15 & 22 \\
\hline 15.3 .2012 & 32 & 3 & 7 & 10 & & & 12 & 0 & 10 & 10 \\
\hline 18.4 .2012 & 89 & & & 33 & 2 & 12 & 14 & 1 & 41 & 42 \\
\hline 16.5 .2012 & 170 & & & 75 & 3 & 39 & 42 & 2 & 51 & 53 \\
\hline 20.6 .2012 & 1047 & & & 373 & & & 191 & & & 483 \\
\hline 16.7.2012 & 1485 & & & 330 & 174 & 169 & 380 & & & 775 \\
\hline 13.8 .2012 & 1406 & & & 371 & & & 309 & & & 726 \\
\hline 17.9 .2012 & 1241 & & & 531 & & & 276 & & & 434 \\
\hline 13.10 .2012 & 1261 & & & 532 & & & 209 & & & 520 \\
\hline 15.11 .2012 & 691 & & & 357 & & & 108 & & & 226 \\
\hline 19.12.2012 & 148 & 68 & 20 & 88 & & & 31 & & & 29 \\
\hline 13.1.2013 & 56 & & & 29 & & & 8 & & & 19 \\
\hline 19.2 .2013 & 39 & 2 & 14 & 20 & 0 & 2 & 2 & 0 & 17 & 17 \\
\hline 22.3 .2013 & 114 & 0 & 17 & 17 & 0 & 18 & 18 & & & 79 \\
\hline 17.4 .2013 & 82 & & & 28 & 0 & 6 & 6 & & & 48 \\
\hline 21.5 .2013 & 395 & 128 & 37 & 165 & & & 83 & & & 147 \\
\hline 17.6.2013 & 905 & 337 & 18 & 355 & & & 195 & & & 355 \\
\hline 17.7.2013 & 1357 & & & 450 & & & 255 & & & 652 \\
\hline 23.8 .2013 & 1494 & 577 & 33 & 610 & & & 269 & & & 615 \\
\hline 17.9 .2013 & 1424 & & & 529 & & & 267 & & & 628 \\
\hline 24.10 .2013 & 1215 & 538 & 38 & 576 & & & 120 & & & 519 \\
\hline
\end{tabular}


'sea state', both having significant coefficients with similar effects as in case of M1.5.

Identification of marine IBA candidates. The density of shags in top $5 \%$ transect segments (i.e. two segments per census occasion) spanned between 4.3 and 72.2 ind. $/ \mathrm{km}^{2}$ in case of all floating shags were considered (ESAS data subset 1), and between 4.3 and 28.7 ind. $/ \mathrm{km}^{2}$ in case of floating shags without those associated with fishing boats (ESAS data subset 2) (Table 6). The spatial distribution of the selected segments was very similar for both ESAS data subsets, resulting in equal distribution of the intersecting grid cells that represent the spatial framework for the delineation of the marine IBA candidate (Figure 3).

\subsection{GPS telemetry}

A total of 29 shags were tagged with GPS loggers between 3.10.2012 and 27.8.2014: 27 at the Izola trapping site and two at the Strunjan trapping site. There was no trapping success at the Sečovlje site.
Two, 15, and 12 Shags were tagged in 2012, 2013 and 2014, respectively. In 2013, several devices stopped working soon after they were mounted on birds due to technical faultiness. The data from the devices that stopped working less than three days after they were mounted on birds (five devices) were excluded from further analysis. Data from 24 birds were thus analysed for the purpose of marine IBA identification.

The tracking data used in the analysis were obtained between 3.10.2012 and 30.9.2014. The number of tracking days in 'clear dataset' differed highly among shags $(n=24)$ : from minimum of five to maximum of 445 days (mean: 78 ) and so did the number of fixed GPS locations: from minimum of 168 to maximum of 8,380 (mean: 1,653). The number of tracking days in 'end dataset' ranged from minimum of 5 to maximum of 437 days (mean: 70) and so did the number of fixed GPS locations: from minimum of 67 to maximum of 3,449 (mean: 608).

The core use areas (kernels) were fit for 21 of 24 individuals. The number of GPS locations in each round foraging trip of three individuals (Andro,

Table 3. Summary of ESAS censuses conducted in the Slovenian sea in 2012 and 2013. Censuses marked with asterisk were conducted within the peak non-breeding season. Duration of census: total census duration including short pauses.

\begin{tabular}{llllllll}
\hline & $\begin{array}{l}\text { Length of } \\
\text { censused }\end{array}$ & $\begin{array}{l}\text { \% of } \\
\text { censused } \\
\text { transect }\end{array}$ & $\begin{array}{l}\text { Census } \\
\text { start time } \\
\text { (h:mm) }\end{array}$ & $\begin{array}{l}\text { Census } \\
\text { end time } \\
\text { (h:mm) }\end{array}$ & $\begin{array}{l}\text { Duration } \\
\text { of census } \\
\text { (h:mm) }\end{array}$ & $\begin{array}{l}\text { No. of } \\
\text { transect } \\
\text { segments }\end{array}$ & $\begin{array}{l}\text { No. of } \\
\text { transect } \\
\text { segments } \\
\mathbf{1 0 0 0 ~ m}\end{array}$ \\
\hline $22.6 .2012^{*}$ & 74.73 & 91.6 & $7: 03$ & $11: 30$ & $4: 27$ & 54 & 6 \\
$17.7 .2012^{*}$ & 81.58 & 100 & $7: 15$ & $11: 41$ & $4: 26$ & 62 & 12 \\
$7.8 .2012^{*}$ & 81.58 & 100 & $7: 53$ & $12: 29$ & $4: 36$ & 60 & 11 \\
$23.8 .2012^{*}$ & 81.58 & 100 & $8: 47$ & $13: 43$ & $4: 56$ & 60 & 12 \\
$7.9 .2012^{*}$ & 81.58 & 100 & $9: 00$ & $13: 54$ & $4: 54$ & 62 & 12 \\
$18.10 .2012^{*}$ & 81.58 & 100 & $11: 09$ & $15: 56$ & $4: 47$ & 59 & 11 \\
16.11 .2012 & 81.58 & 100 & $10: 30$ & $14: 52$ & $4: 22$ & 61 & 12 \\
19.12 .2012 & 81.58 & 100 & $10: 18$ & $15: 05$ & $4: 47$ & 60 & 12 \\
23.1 .2013 & 81.58 & 100 & $9: 58$ & $14: 06$ & $4: 08$ & 58 & 10 \\
19.2 .2013 & 81.58 & 100 & $11: 05$ & $15: 36$ & $4: 31$ & 62 & 13 \\
22.3 .2013 & 81.58 & 100 & $11: 00$ & $15: 32$ & $4: 32$ & 60 & 12 \\
19.4 .2013 & 81.58 & 100 & $11: 10$ & $15: 31$ & $4: 21$ & 60 & 12 \\
21.5 .2013 & 41.55 & 50.9 & $11: 30$ & $14: 22$ & $2: 52$ & 33 & 9 \\
$19.6 .2013^{*}$ & 81.58 & 100 & $11: 14$ & $15: 53$ & $4: 39$ & 57 & 9 \\
$26.7 .2013^{*}$ & 81.58 & 100 & $10: 55$ & $16: 35$ & $5: 40$ & 59 & 11 \\
$23.8 .2013^{*}$ & 81.58 & 100 & $10: 47$ & $15: 08$ & $4: 21$ & 60 & 12 \\
\hline Total & $\mathbf{1 . 2 5 8 , 4}$ & & & & $72: 19$ & $\mathbf{9 2 7}$ & $\mathbf{1 7 6}$ \\
\hline
\end{tabular}




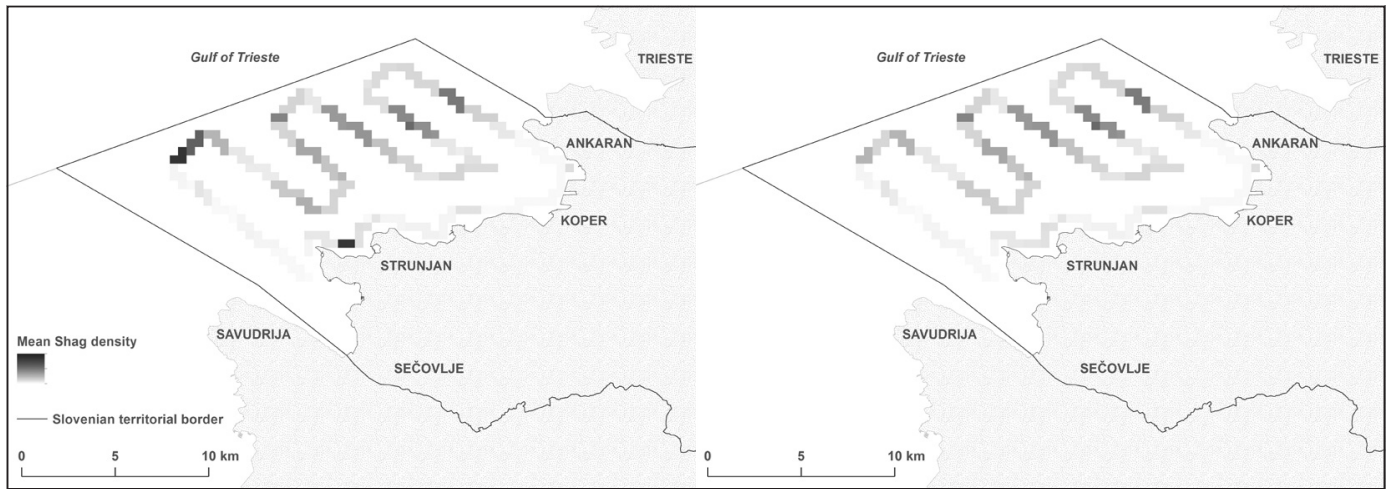

Figure 2. Mean densities of the Mediterranean Shags Phalacrocorax aristotelis desmarestii (ind./ $/ \mathrm{km}^{2}$ ) at the ESAS transect in peak non-breeding season; the data were pooled for the years 2012 and 2013. Left: density of all floating shags; right: density of floating shags without those associated with fishing boats.

Roko and Dino) was below the required threshold (i.e. six locations) to fit the kernels. The number of fit core use areas varied greatly between the individuals (1-112) (Table 7), as well as between roost-sites
(1-160) (Table 8). Mean surface area of core use areas was $383.79 \pm 222.56$ ha. Mean distance from the coast, calculated as aerial distance of core use area central point from the corresponding roost-

Table 4. Models of the Mediterranean Shag Phalacrocorax aristotelis desmarestii distribution in the Slovenian territorial sea in peak non-breeding season; the data were pooled for the years 2012 and 2013. Set 1: the response variable was defined as the number of all floating individuals in a transect segment (ESAS data subset 1). Set 2: the response variable was defined as the number of floating individuals not associated with fishing boats in a transect segment (ESAS data subset 2). The selected models in each set are printed in bold. Fixed variables included in a given model are denoted with ' $Y$ '. Distance: distance from the coast; Sfishb: presence of small $(<12 \mathrm{~m})$ fishing boats; Lfishb <0.5 km: presence of large ( $>12 \mathrm{~m}$ ) fishing boats $<0.5 \mathrm{~km}$ away; Lfishb $\mathbf{0 . 5}-\mathbf{2} \mathbf{~ k m}$ : presence of large fishing boats $0.5-2 \mathrm{~km}$ away; Sediment: sediment type; Sea state: sea state on the Beaufort scale; *GAM was fit. **Model did not converge.

\begin{tabular}{|c|c|c|c|c|c|c|c|c|c|c|c|c|}
\hline \multirow[b]{2}{*}{$\begin{array}{l}\text { Set of } \\
\text { models }\end{array}$} & \multirow[b]{2}{*}{ Model } & \multirow[b]{2}{*}{$\begin{array}{l}\text { Degrees of } \\
\text { freedom }\end{array}$} & \multirow[b]{2}{*}{ AIC } & \multirow[b]{2}{*}{$\Delta \mathrm{AIC}$} & \multirow[b]{2}{*}{$\begin{array}{l}\text { Random } \\
\text { variable } \\
\text { Date }\end{array}$} & \multicolumn{7}{|c|}{ Fixed variables } \\
\hline & & & & & & 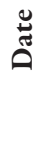 & 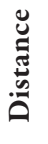 & $\frac{0}{\frac{1}{n}}$ & 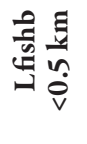 & 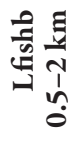 & 䒕 & 节 \\
\hline \multirow{7}{*}{ Set 1} & M1.5 & 11 & 1439.4 & 0 & census date & \multirow{7}{*}{$\mathrm{Y}$} & $\mathbf{Y}$ & $\mathbf{Y}$ & $\mathbf{Y}$ & $\mathbf{Y}$ & & $\mathbf{Y}$ \\
\hline & M1.6 & 8 & 1449.6 & 10.2 & census date & & $\mathrm{Y}$ & $\mathrm{Y}$ & $\mathrm{Y}$ & $\mathrm{Y}$ & & \\
\hline & M1.2 & 13 & 1451.6 & 12.2 & census date & & $\mathrm{Y}$ & $\mathrm{Y}$ & $\mathrm{Y}$ & $\mathrm{Y}$ & $\mathrm{Y}$ & $\mathrm{Y}$ \\
\hline & M1.1 & 17 & 1467.8 & 28.4 & none* & & $\mathrm{Y}$ & $\mathrm{Y}$ & $\mathrm{Y}$ & $\mathrm{Y}$ & $\mathrm{Y}$ & $\mathrm{Y}$ \\
\hline & M1.7 & 8 & 1536.9 & 97.5 & census date & & $\mathrm{Y}$ & & & & & Y \\
\hline & M1.3 & 5 & 1539.6 & 100.2 & census date & & $\mathrm{Y}$ & & & & & Y \\
\hline & $\mathrm{M} 1.4^{* *}$ & 7 & 1540.9 & 101.5 & census date & & $\mathrm{Y}$ & & & & $\mathrm{Y}$ & \\
\hline \multirow{5}{*}{ Set 2} & M2.5 & 8 & 1437.54 & 0 & census date & \multirow{5}{*}{$\mathrm{Y}$} & $\mathbf{Y}$ & & & & & $\mathbf{Y}$ \\
\hline & M2.2 & 10 & 1449.35 & 11.81 & census date & & $\mathrm{Y}$ & & & & $\mathrm{Y}$ & $\mathrm{Y}$ \\
\hline & M2.3 & 5 & 1452.98 & 15.44 & census date & & $\mathrm{Y}$ & & & & & \\
\hline & M2.1 & 14 & 1457.27 & 19.73 & none* & & $\mathrm{Y}$ & & & & $\mathrm{Y}$ & Y \\
\hline & M2.4 & 7 & 1468.32 & 30.78 & census date & & $\mathrm{Y}$ & & & & $\mathrm{Y}$ & \\
\hline
\end{tabular}


Table 5. Regression coefficients of the selected GAMM models describing distribution of the Mediterranean Shags Phalacrocorax aristotelis desmarestii at the Slovenian sea in peak non-breeding season; M1.5: the response variable was defined as the number of all floating individuals in a transect segment (ESAS data subset 1). M2.5: the response variable was defined as the number of floating individuals not associated with fishing boats in a transect segment (ESAS data subset 2). te: denoting the smoothing function used in the additive modelling. Sea state referential level: Beaufort level 0.

\begin{tabular}{|c|c|c|c|c|c|}
\hline Model & Predictor & & Description & B & $\mathbf{p}$ \\
\hline \multirow{9}{*}{ M1.5 } & \multicolumn{2}{|l|}{ Intercept } & Model intercept & -12.9 & $<0.001$ \\
\hline & \multicolumn{2}{|l|}{ te(Distance) } & Distance from the coast & 1.22 & $<0.001$ \\
\hline & \multicolumn{2}{|l|}{ Sfishb } & Presence of small $(<12 \mathrm{~m})$ fishing boats & 0.20 & non-sig. \\
\hline & \multicolumn{2}{|l|}{ Lfishb $<0.5 \mathrm{~km}$} & $\begin{array}{l}\text { Presence of large }(>12 \mathrm{~m}) \text { fishing boats } \\
0.5 \mathrm{~km} \text { away }\end{array}$ & 2.74 & $<0.001$ \\
\hline & \multicolumn{2}{|l|}{ Lfishb $0.5-2 \mathrm{~km}$} & $\begin{array}{l}\text { Presence of large }(>12 \mathrm{~m}) \text { fishing boats } \\
0.5-2 \mathrm{~km} \text { away }\end{array}$ & 0.87 & $<0.05$ \\
\hline & \multirow{4}{*}{ Sea state } & level = 1 & \multirow{4}{*}{ Sea state on the Beaufort scale } & -0.53 & $<0.05$ \\
\hline & & level = 2 & & -0.89 & $<0.01$ \\
\hline & & level $=3$ & & -1.33 & $<0.01$ \\
\hline & & level $=5$ & & -0.77 & non-sig. \\
\hline \multirow{6}{*}{ M2.5 } & \multirow{2}{*}{\multicolumn{2}{|c|}{$\begin{array}{l}\text { Intercept } \\
\text { te(Distance) }\end{array}$}} & Model intercept & -12.8 & $<0.001$ \\
\hline & & & Distance from the coast & 1.33 & $<0.001$ \\
\hline & \multirow{4}{*}{ Sea state } & level = 1 & \multirow{4}{*}{ Sea state on Beaufort scale } & -0.59 & $<0.01$ \\
\hline & & level = 2 & & -1.06 & $<0.001$ \\
\hline & & level $=3$ & & -1.50 & $<0.01$ \\
\hline & & level $=5$ & & -0.84 & non-sig. \\
\hline
\end{tabular}

site was $3.61 \pm 2.3 \mathrm{~km}$. Nine of 21 individuals were using more than one roost-site (Table 7).

Using the GPS telemetry data, eight marine IBA candidates were identified in total, based on the individuals making round foraging trips from roost-sites 1, 3 and 5 (Figure 6). No sites were identified based on foraging trips from other roost sites (Table 9). It was estimated that the maximum numbers of shags visiting individual areas ranged between 7 and 220 individuals (Table 10).

\subsection{Census of large floating groups}

A total of 40 cases of large floating groups $(\geq 10$ individuals) of the Mediterranean Shags were reported between October 2011 and November 2014 (Table 11, Figure 7). All reports coincide with the autumn season, the earliest being from 21th September and the latest from 6th December.
$13(32.5 \%)$ groups consisted of 130 or more individuals, the largest two groups holding 300 and 310 individuals. $69.2 \%$ of groups with 130 or more individuals and $40.7 \%$ of groups with less than 130 individuals were observed during active foraging, in several cases in the company of Black-headed Gulls (Chroicocephalus ridibundus). Most groups were foraging in the intertidal zone preying on schools of small pelagic fish.

\subsection{Data layer classification}

The spatial data layers produced based on the ESAS dataset were classified as primary and the spatial data layers produced based on the GPS telemetry data and census of large floating groups as supplementary (Table 12). An additional environmental layer, i.e. the bathymetry layer, was used for a detailed delineation of final marine IBA borders. 


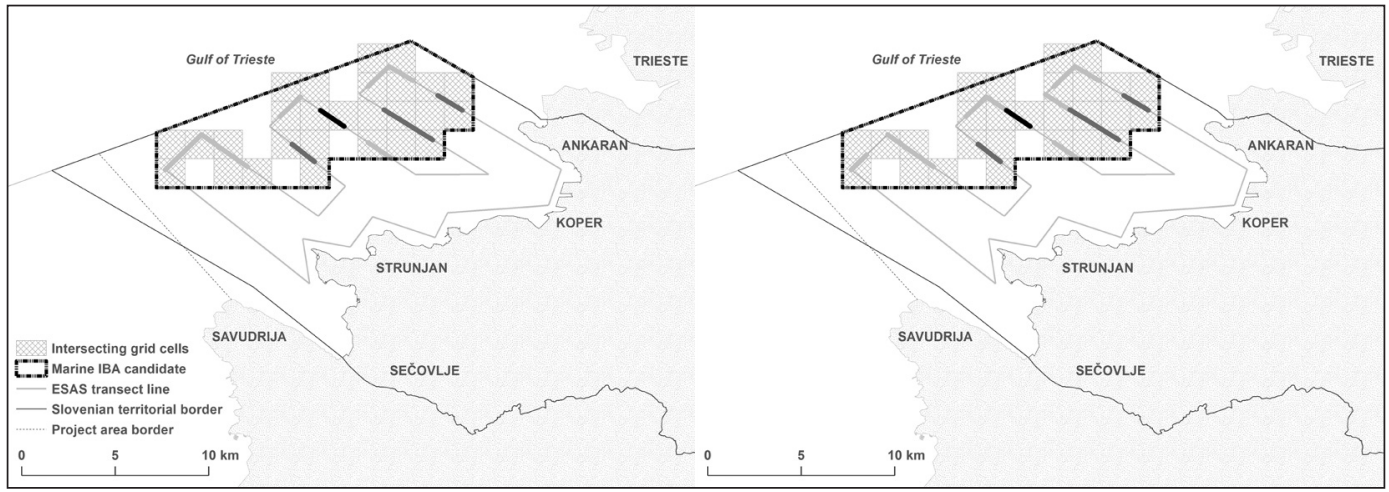

Figure 3. Marine IBA candidate as identified based on the locations of the top 5\% transect segments with the highest densities of the Mediterranean Shags Phalacrocorax aristotelis desmarestii in peak non-breeding season in 2012 and 2013; light grey segments: year 2012; dark grey segments: year 2013; black segments: both years. Left: density of all floating shags; right: density of floating shags without those associated with fishing boats. The segments are overlaid with intersecting grid cells $(a=1,540 \mathrm{~m})$, representing the spatial framework for the delineation of the marine IBA candidate.

Table 6. Densities of the Mediterranean Shags Phalacrocorax aristotelis desmarestii in the top 5\% transect segments in peak non-breeding season by census occasion. The densities were calculated based on the number of all floating shags (ESAS data subset 1 ) or the number of floating shags without those associated with fishing boats (ESAS data subset 2). *Transect segments differ between data subsets.

\begin{tabular}{lll}
\hline & \multicolumn{2}{l}{$\begin{array}{l}\text { Mediterranean Shag density } \\
{\left[\text { ind./ } \mathbf{k m}^{2}\right]}\end{array}$} \\
\cline { 2 - 3 } Census date & $\begin{array}{l}\text { ESAS data } \\
\text { subset 1 }\end{array}$ & $\begin{array}{l}\text { ESAS data } \\
\text { subset 2 }\end{array}$ \\
\hline 17.7.2012 & 21.6 & 21.6 \\
& 19.3 & 19.3 \\
7.8 .2012 & $56.3^{*}$ & $4.3^{*}$ \\
& 13.0 & 13.0 \\
23.8 .2012 & $72.2^{*}$ & $7.9^{*}$ \\
& 10.8 & 10.8 \\
7.9 .2012 & 5.4 & 5.4 \\
& 4.3 & 4.3 \\
18.10 .2012 & 10.0 & 10.0 \\
& 5.4 & 5.4 \\
19.6 .2013 & 26.0 & 24.9 \\
& 15.2 & 15.2 \\
26.7 .2013 & 28.7 & 28.7 \\
& 21.6 & 21.6 \\
23.8 .2013 & 19.5 & 19.5 \\
& 11.9 & 11.9 \\
\hline
\end{tabular}

\subsection{New marine IBA proposals and their compliance with the IBA criteria}

\subsubsection{Marine IBA proposals}

The final marine IBA proposals for the Mediterranean Shags were delineated based on the IBA candidates that were identified as part of the analysis of the three data sources: ESAS dataset (Figure 3), GPS telemetry dataset (Figure 6), and land-based observations of large foraging groups (Figure 7). One new marine IBA and one extension to an existing marine IBA were delineated (Figure 8). The IBA Osrednji Tržaški zaliv was delineated based on one primary data layer (Table 13). The extension to IBA Debeli rtič was delineated based on two overlapping supplementary data layers and the bathymetry layer as an additional environmental data layer to limit the area to $0-10 \mathrm{~m}$ depth zone, as social foraging of shags on schools of small pelagic fish occurred most intensively in the shallow in-shore waters and the intertidal zone (Table 13). The new proposed areas and the previously identified IBAs represent four distinct IBAs for the Mediterranean Shag in the Slovenian territorial sea (Figure 8). Note that the marine IBA Škocjanski zatok does not include the Mediterranean Shag as a qualifying species. 


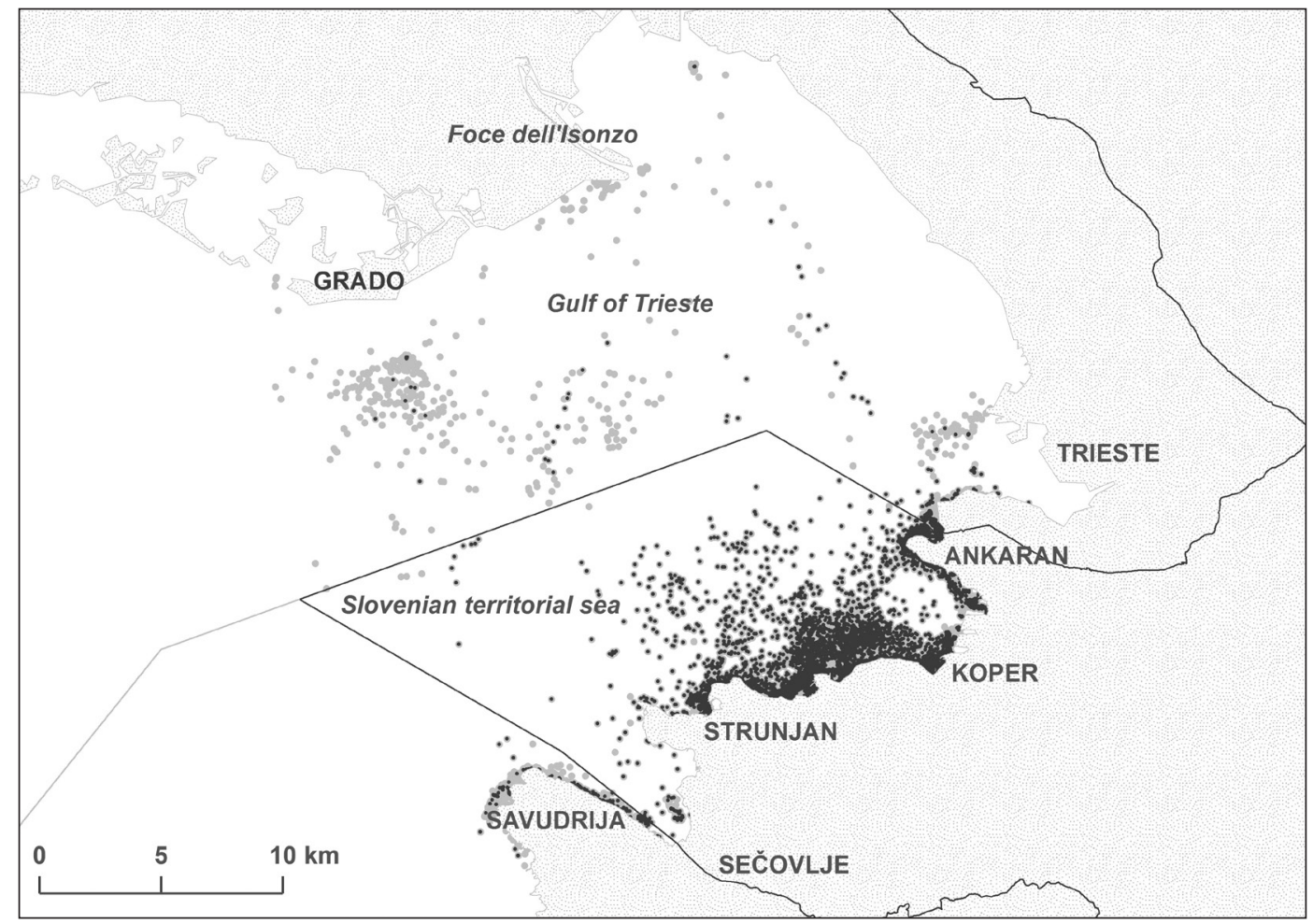

Figure 4. GPS locations of 24 Mediterranean Shags Phalacrocorax aristotelis desmarestii within the Gulf of Trieste, tagged along the Slovenian coast and tracked between 3.10.2012-30.9.2014; grey dots: clear dataset $(n=39,670)$; black dots: end dataset $(n=14,595)$
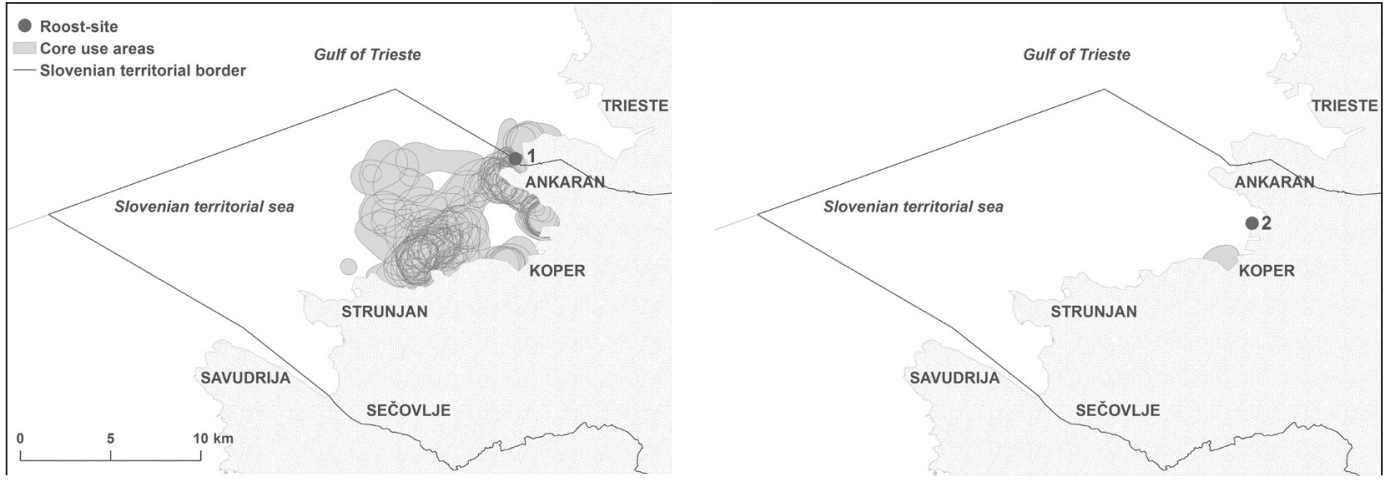


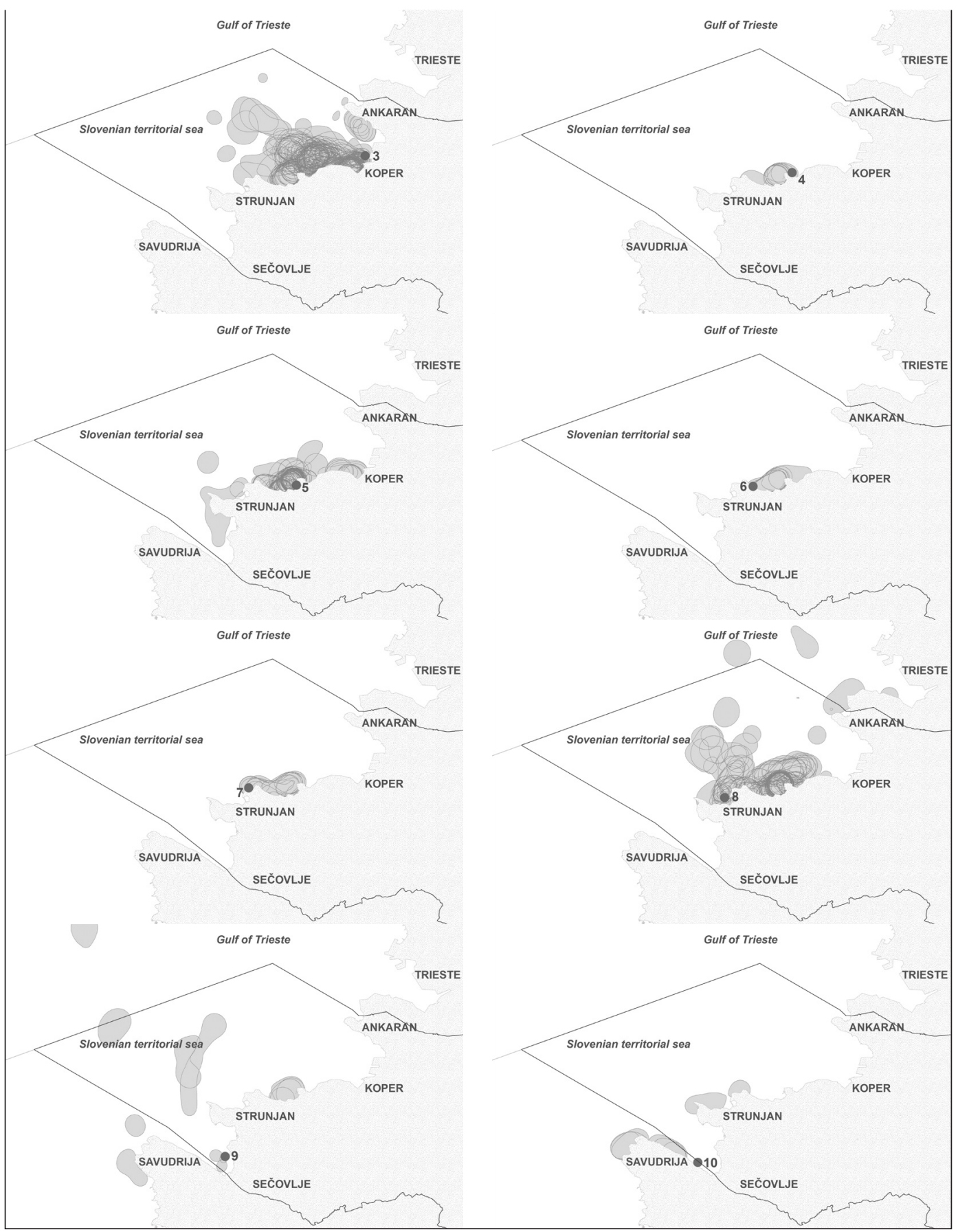

Figure 5. Core use areas of 21 of 24 tracked Mediterranean Shags Phalacrocorax aristotelis desmarestii making round foraging trips from roost-sites $1-10$. Note that no core use areas were identified for three individuals (Andro, Dino and Roko). Numbers 1, 8 and 9 represent the main communal roost-sites along the Slovenian coast, Debeli rtič, Strunjan and Sečovlje, respectively. 
Table 7. Core use area (CUA) statistics by individuals for 21 Mediterranean Shags Phalacrocorax aristotelis desmarestii. Note that no core use areas were identified for three individuals, Andro, Dino and Roko.

\begin{tabular}{lllllll}
\hline Individual & No. of CUA & $\begin{array}{l}\text { Mean surface } \\
\text { area }(\mathbf{h a})\end{array}$ & SD (ha) & $\begin{array}{l}\text { Mean coast } \\
\text { distance }(\mathbf{k m})\end{array}$ & SD $(\mathbf{k m})$ & $\begin{array}{l}\text { No. of roost- } \\
\text { sites }\end{array}$ \\
\hline Ante & 1 & 147.24 & NA & 1.90 & NA & 1 \\
Ari & 3 & 457.79 & 77.48 & 1.34 & 1.36 & 1 \\
Bepo & 29 & 630.59 & 203.39 & 5.50 & 5.68 & 1 \\
Dado & 6 & 220.65 & 27.12 & 0.71 & 0.69 & 2 \\
Ilija & 4 & 871.15 & 392.35 & 11.62 & 8.65 & 1 \\
Ivek & 8 & 238.30 & 33.89 & 1.55 & 1.50 & 1 \\
Jakomo & 112 & 240.37 & 101.77 & 2.89 & 3.61 & 4 \\
Karlo & 44 & 595.18 & 164.78 & 6.59 & 6.74 & 2 \\
Mihi & 69 & 395.54 & 144.60 & 3.78 & 3.94 & 4 \\
Momo & 4 & 389.72 & 71.13 & 2.47 & 1.47 & 1 \\
Nace & 38 & 254.11 & 83.20 & 2.59 & 3.21 & 1 \\
Nikola & 63 & 587.95 & 209.13 & 4.50 & 4.38 & 3 \\
Ogi & 10 & 678.16 & 235.74 & 5.79 & 5.81 & 1 \\
Oto & 2 & 861.29 & 94.64 & 3.33 & 3.33 & 1 \\
Pino & 15 & 246.68 & 93.74 & 2.77 & 2.00 & 3 \\
Srečko & 26 & 332.43 & 77.60 & 1.75 & 1.56 & 4 \\
Šime & 5 & 329.61 & 169.54 & 2.67 & 2.87 & 1 \\
Śtelio & 10 & 459.52 & 312.37 & 3.38 & 3.15 & 1 \\
Tartini & 10 & 527.98 & 179.13 & 2.93 & 2.62 & 1 \\
Tonin & 3 & 264.21 & 17.46 & 1.23 & 1.41 & 2 \\
Ugo & 55 & 183.21 & 68.87 & 2.58 & 1.69 & 3 \\
\hline & & & & & & \\
\hline
\end{tabular}

Table 8. Core use area (CUA) statistics by roost-sites for 21 Mediterranean Shags Phalacrocorax aristotelis desmarestii. Note that no core use areas were identified for three individuals, Andro, Dino and Roko.

\begin{tabular}{lllllll}
\hline Roost-site & No. of CUA & $\begin{array}{l}\text { Mean area } \\
\text { (ha) }\end{array}$ & SD (ha) & $\begin{array}{l}\text { Mean coast } \\
\text { distance }(\mathbf{k m})\end{array}$ & SD(km) & $\begin{array}{l}\text { No. of } \\
\text { individuals }\end{array}$ \\
\hline 1 & 119 & 426.76 & 223.89 & 4.70 & 2.38 & 9 \\
2 & 1 & 169.12 & NA & 2.76 & NA & 1 \\
3 & 160 & 420.45 & 220.79 & 3.82 & 1.81 & 7 \\
4 & 8 & 246.32 & 36.12 & 1.31 & 0.45 & 2 \\
5 & 93 & 243.58 & 122.23 & 1.33 & 1.21 & 7 \\
6 & 8 & 335.92 & 30.25 & 1.69 & 0.58 & 1 \\
7 & 10 & 385.34 & 79.38 & 2.13 & 0.54 & 1 \\
8 & 103 & 412.11 & 246.93 & 4.10 & 1.51 & 8 \\
9 & 8 & 584.18 & 406.85 & 9.20 & 5.04 & 2 \\
10 & 7 & 272.95 & 128.14 & 4.29 & 1.78 & 1 \\
\hline
\end{tabular}




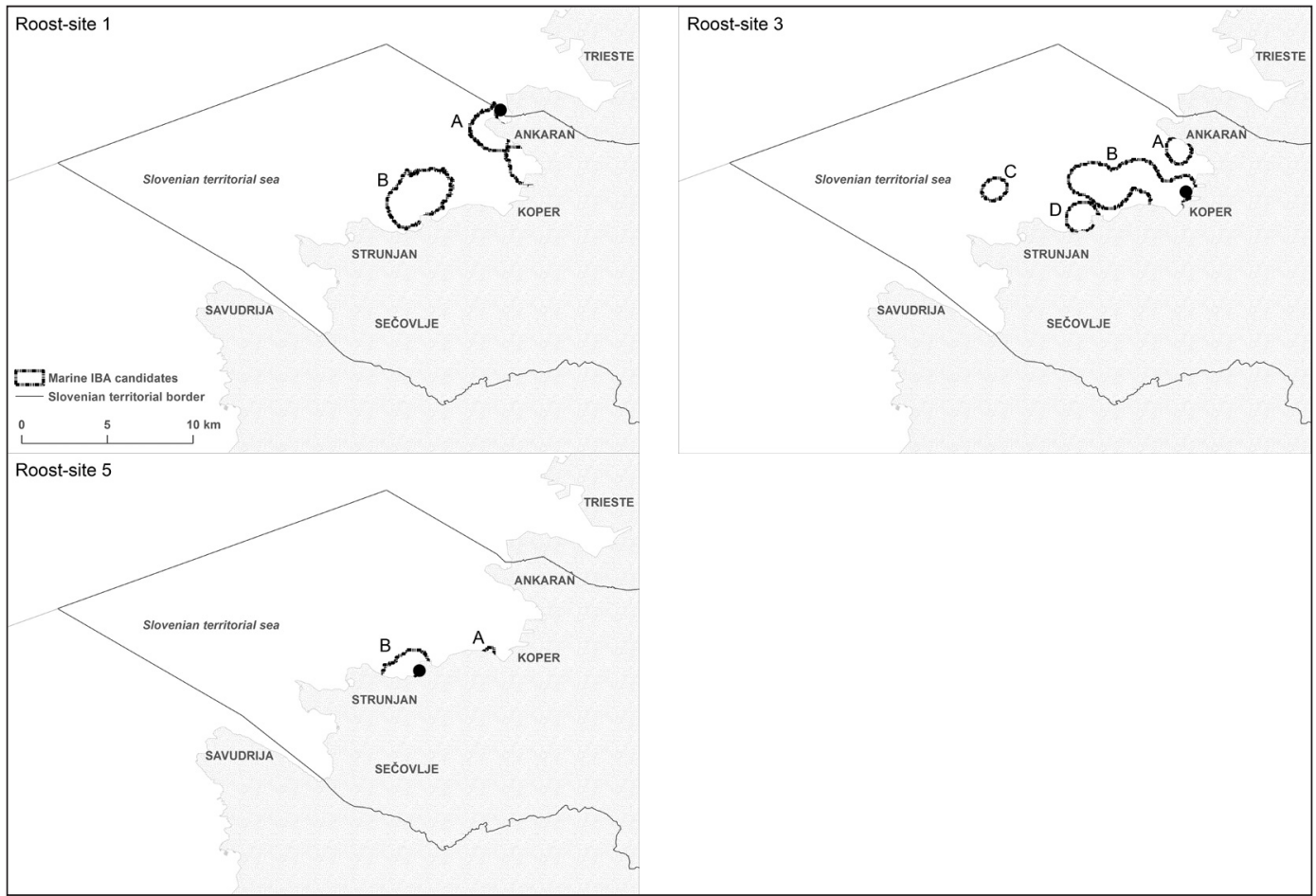

Figure 6. Marine IBA candidates as identified in the analysis of the GPS telemetry data of 21 Mediterranean Shags Phalacrocorax aristotelis desmarestii tagged along the Slovenian coast and tracked between 3.10.2012-30.9.2014. Note that no candidates were identified for shags roosting at roost-sites 2, 4, 6-7 and 9-10. Letters A to D denote individual IBA candidates.

Table 9. Parameters and outcomes of the identification of marine IBA candidates based on the GPS telemetry data of 21 Mediterranean Shags Phalacrocorax aristotelis desmarestii tagged along the Slovenian coast and tracked between 3.10.2012-30.9.2014.

\begin{tabular}{lllllll}
\hline Roost-site & $\begin{array}{l}\text { Inner } \\
\text { buffer }[\mathbf{k m}]\end{array}$ & $\begin{array}{l}\text { Outer } \\
\text { buffer }[\mathbf{k m}]\end{array}$ & Ars scale & Site fidelity & $\begin{array}{l}\text { Sample } \\
\text { representa- } \\
\text { tiveness }\end{array}$ & $\begin{array}{l}\text { Resulting marine } \\
\text { IBA candidates }\end{array}$ \\
\hline 1 (Debeli rtič) & 0.7 & 0.7 & 0.732 & non-significant & 97.42 & 1 A-B \\
2 & 0.3 & 0.3 & & $/$ & & sample too small \\
3 & 0.35 & 0.35 & 0.675 & significant & 79.8 & 3A-D \\
4 & 0.4 & 0.4 & 0.7 & $/$ & & sample too small \\
5 & 0.3 & 0.5 & 0.545 & non-significant & 99.31 & 5A-B \\
6 & 0.2 & 0.2 & 0.600 & $/$ & & sample too small \\
7 & 0.2 & 0.2 & 0.629 & $/$ & & sample too small \\
8 (Strunjan) & 0.4 & 0.4 & 0.829 & significant & 56.07 & $\begin{array}{l}\text { sample not } \\
\text { representative }\end{array}$ \\
9 (Sečovlje) & 0.6 & 0.6 & 1.471 & $/$ & & sample too small \\
10 & 0.3 & 0.3 & 1.067 & $/$ & & sample too small \\
\hline
\end{tabular}


Table 10. Marine IBA candidates identified based on the GPS telemetry data of the Mediterranean Shags Phalacrocorax aristotelis desmarestii in the Slovenian sea, and estimates of the number of individuals utilizing each area. Roost-sites represent the central place of round foraging trips of the shags.

\begin{tabular}{llllll}
\hline Roost-site & Area ID & Surface area [ha] & $\begin{array}{l}\text { Roosting } \\
\text { population }\end{array}$ & $\begin{array}{l}\text { max. \% of roosting } \\
\text { population }\end{array}$ & $\begin{array}{l}\text { max. mIBA site } \\
\text { population }\end{array}$ \\
\hline \multirow{2}{*}{1} & A & 573 & & 24.37 & $129-149$ \\
& B & 888 & $530-610^{1}$ & 36.13 & $191-220$ \\
& A & 168 & & 14.29 & 14 \\
3 & B & 1407 & $\sim 100^{2}$ & 57.14 & 57 \\
& C & 147 & & 14.29 & 14 \\
& D & 239 & & 14.29 & 14 \\
& A & 14 & $\sim 50^{2}$ & 12.9 & 7 \\
\hline
\end{tabular}

Roost-site monitoring yearly maxima in 2012 and 2013;

numbers assessed based on land observations (best expert opinion).

Table 11. The number of groups of the Mediterranean Shags Phalacrocorax aristotelis desmarestii along the Slovenian coast from October 2011 to December 2014 by months and years; the data were reported by random observers; Total foraging: number of groups observed during active foraging. The number in brackets denotes the number of groups with $\geq 300$ individuals.

\begin{tabular}{lll}
\hline Month & $<\mathbf{1 3 0}$ ind. & $\geq \mathbf{1 3 0}$ ind. \\
\hline September & 1 & 4 \\
October & 11 & $7(2)$ \\
November & 14 & 2 \\
December & 1 & 0 \\
\hline Year & $<\mathbf{1 3 0}$ ind. & $\geq \mathbf{1 3 0}$ ind. \\
\hline 2011 & 0 & $2(1)$ \\
2012 & 9 & 5 \\
2013 & 10 & 3 \\
2014 & 8 & $3(1)$ \\
Total & $\mathbf{2 7}$ & $\mathbf{1 3}(2)$ \\
\hline Total foraging & $\mathbf{1 1}$ & $\mathbf{9 ( 2 )}$ \\
\hline
\end{tabular}

\subsubsection{Estimated numbers of the Mediterranean Shags in proposed IBAs}

Estimates based on extrapolation: Estimated number of shags in the target area was the highest in
July 2013 and the lowest in March 2013 (Table 14). The estimated number of shags in the proposed IBA Osrednji Tržaški zaliv (OTZ) exceeded 300 individuals (1\% of biogeographic population) in 5 out of 8 censuses within the peak non-breeding season, i.e. in July 2012, twice in August 2012, in June 2013 and July 2013 (Table 14). The mean number in summer months, pooled for both monitoring years, was 374 individuals (321-427, $90 \% \mathrm{CI}$ ). The probability that the mean was lower than 300 individuals was below 5\% (Student $\mathrm{t}=2.8, \mathrm{df}=5, \mathrm{p}=0.02$ ).

Estimates based on the models: The estimated mean number of all floating shags within the Slovenian territorial sea was 866 (471-1,705, 90\% CI), and 495 (265-988, $90 \%$ CI) within the IBA Osrednji Tržaški zaliv (predictions from the model M1.5). The estimated mean number of floating shags without individuals associated with fishing boats was 745 (472-1,187, 90\% CI) within the Slovenian territorial sea and $415(263-658,90 \% \mathrm{CI})$ within the IBA Osrednji Tržaški zaliv (predictions from the model M2.5). Note that the predictions of the models account for the number of shags averaged over the entire peak non-breeding season and are thus not directly comparable with the estimates based on extrapolation (expressed as mean number of shags in summer months). 


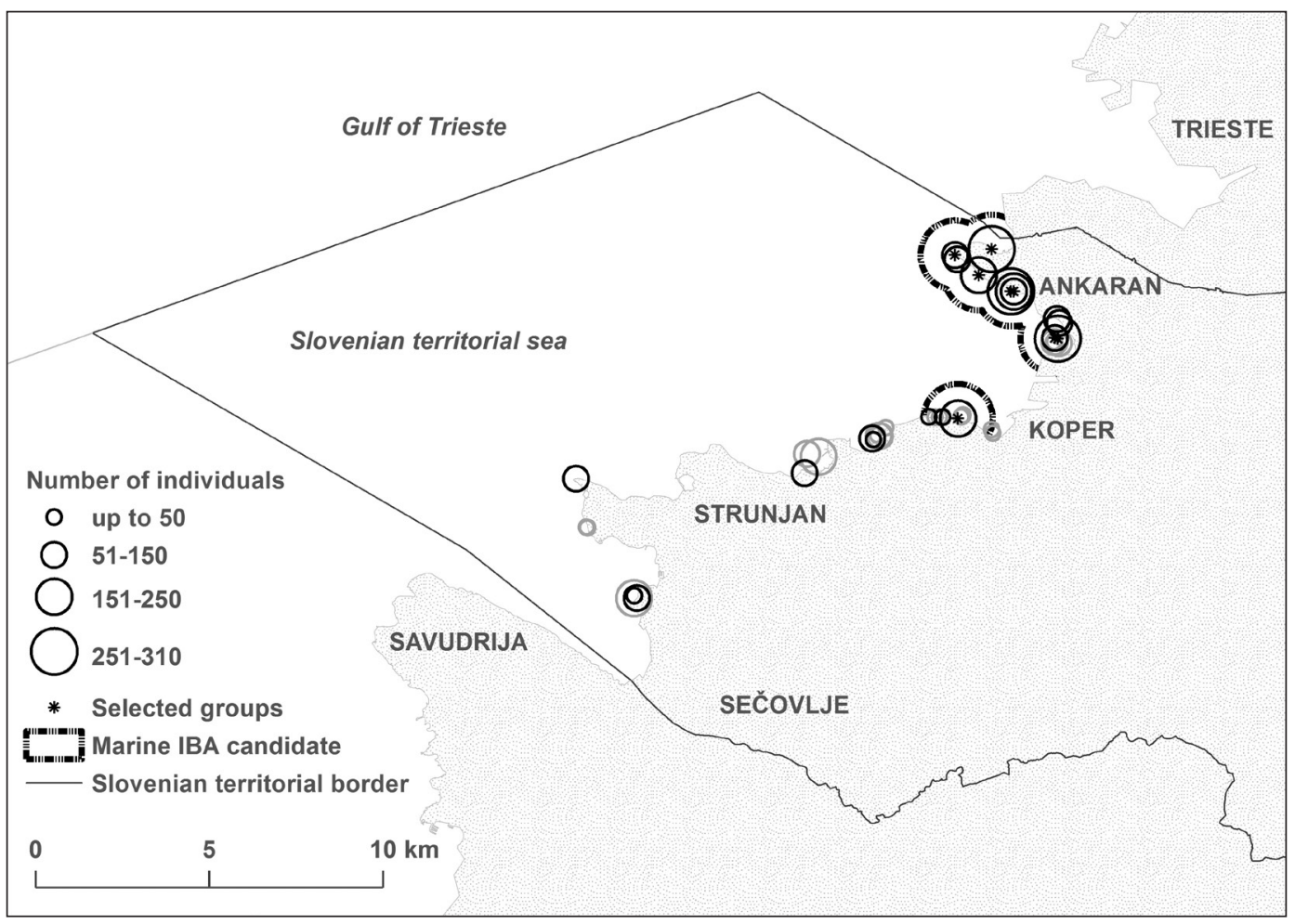

Figure 7. Large groups ( $\geq 10$ individuals) of the Mediterranean Shags Phalacrocorax aristotelis desmarestii randomly registered between October 2011 and November 2014 along the Slovenian coast; black circles: the group was observed during active foraging; grey circles: the group was not actively foraging; the groups selected for delineation of marine IBA candidates are marked with asterisk.

Table 12. Classification of the spatial data layers used for delineation of marine IBA candidates for the Mediterranean Shag Phalacrocorax aristotelis desmarestii in the Slovenian sea.

\begin{tabular}{llll}
\hline & Data layer & Data source & Data layer class \\
\hline 1 & $\begin{array}{l}\text { local densities of shags in the peak non- } \\
\text { breeding season, i.e. top 5\% transect segments } \\
\text { with highest densities (the best segments) }\end{array}$ & ESAS monitoring & primary \\
2 & $\begin{array}{l}\text { grid cells }(1,540 \mathrm{~m} \text { ) intersecting with the best } \\
\text { transect segments }\end{array}$ & sPS telemetry \\
3 & core use areas of individual tracked shags & $\begin{array}{l}\text { unsystematic land-based census } \\
\text { Geodetic Administration of the } \\
\text { Republic of Slovenia (GURS) }\end{array}$ & supplementary \\
4 & large foraging groups of shags & environmental \\
\hline
\end{tabular}




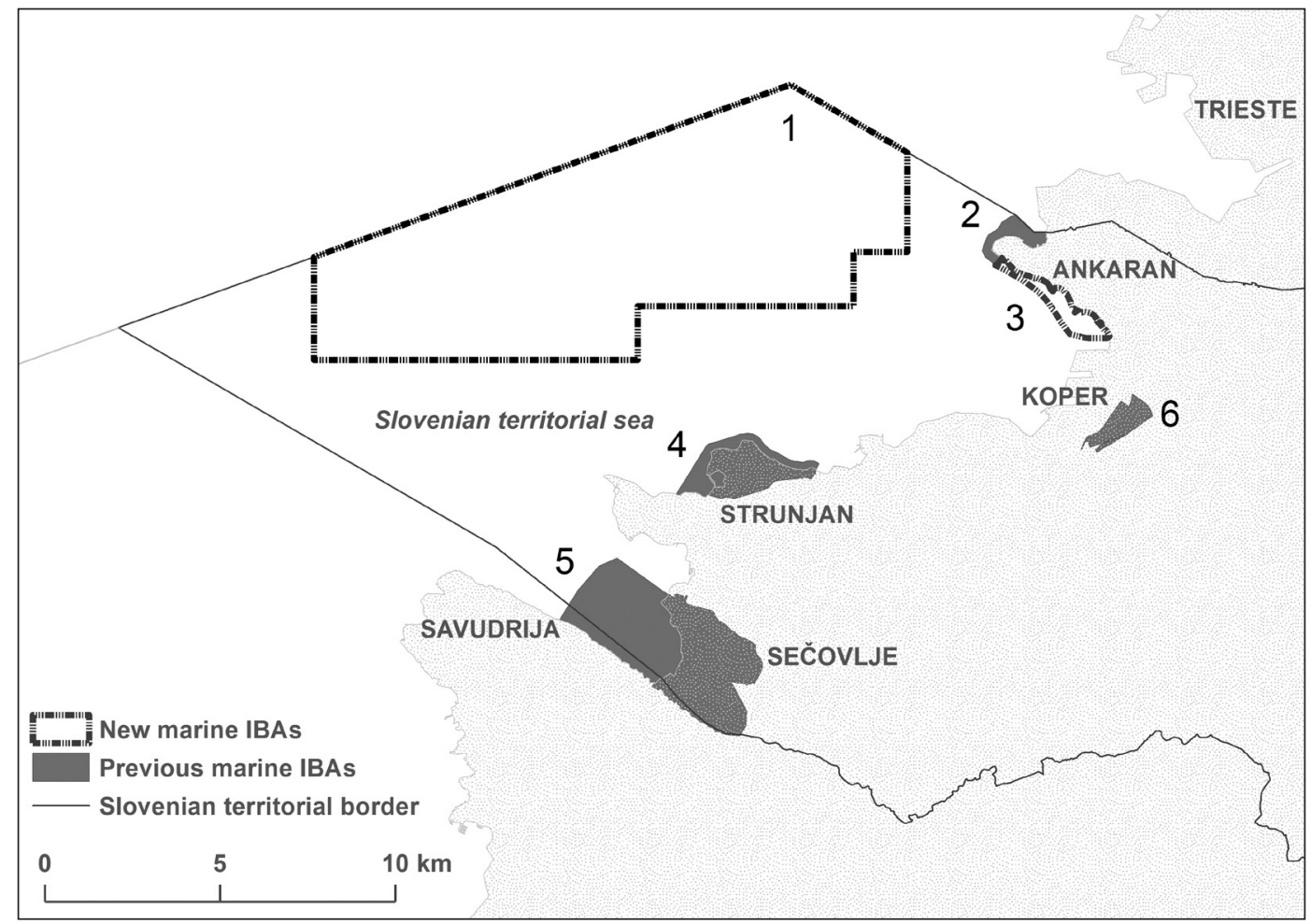

Figure 8. Marine IBAs in Slovenia; dashed line: new marine IBAs for the Mediterranean Shag Phalacrocorax aristotelis desmarestii identified within the scope of the SIMARINE-NATURA project (this work); dark grey polygons: marine IBAs identified during previous stages in 2000-2011 (DenAC et. al 2011). 1: IBA Osrednji Tržaški zaliv; 2: IBA Debeli rtič; 3: extension to IBA Debeli rtič; 4: IBA Strunjan; 5: IBA Sečoveljske soline; 6: IBA Škocjanski zatok. IBAs 2, 4 and 5 cover the three main roost-sites of the Mediterranean Shags along the Slovenian coast. The IBA Sečoveljske soline crosses the national border since it was identified before the marine border between Slovenia and Croatia was defined in the arbitration. Note that the IBA Škocjanski zatok does not include the Mediterranean Shag as a qualifying species.

\section{Discussion}

The Slovenian territorial sea has been previously recognized as an area of international importance for the Mediterranean Shag in the non-breeding season (Denac et al. 2011, Koce \& Lipej 2016), however, this work delivers important new knowledge about the spatio-temporal distribution of this seabird within the area. Two new marine IBAs for the Mediterranean Shag were identified based on the results of this study, which essentially complement the previously existing marine IBAs covering three main communal roost-sites on the shellfish farms located along the Slovenian coast (Denac et al. 2011). The main added value of the new sites to the conservation of the global non-breeding population of the Mediterranean Shag is that they encompass two areas regularly used for foraging by at least $1 \%$ of the population.

The two new areas, IBA Osrednji Tržaški zaliv and the extension to the existing IBA Debeli rtič, differ in their ecological characteristics reflected in different ways the shags are using them. The IBA Osrednji Tržaški zaliv covers an off-shore area, spanning between approximately 3.5 and $10 \mathrm{~km}$ from the coast and lying within the $20-25 \mathrm{~m}$ depth zone, dominated by muddy and sandy benthic substrate and corresponding benthic community that is poorly investigated (PETERLIN et al. 2013). We suggest that its importance for the foraging 
Table 13. Marine IBAs proposed based on the data on the Mediterranean Shag Phalacrocorax aristotelis desmarestii distribution and numbers, gathered within the project SIMARINE-NATURA (LIFE1ONAT/SI/141) in 2011-2014.

\begin{tabular}{|c|c|c|c|c|c|}
\hline $\begin{array}{l}\text { Marine IBA } \\
\text { proposal }\end{array}$ & $\begin{array}{l}\text { Underlying } \\
\text { data sources }\end{array}$ & $\begin{array}{l}\text { Surface } \\
\text { area (ha) }\end{array}$ & $\begin{array}{l}\text { Estimated } \\
\text { population size }\end{array}$ & Regularity of use & $\begin{array}{l}\text { Complies with } \\
\text { IBA criteria }\end{array}$ \\
\hline $\begin{array}{l}\text { IBA Osrednji } \\
\text { Tržaški zaliv }\end{array}$ & - ESAS dataset & 8.218 ha & $\begin{array}{l}374(321-427,90 \% \mathrm{CI})^{1} \\
495(265-988,90 \% \mathrm{CI})^{2}\end{array}$ & $\begin{array}{l}1 \% \text { population } \\
\text { threshold exceeded } \\
\text { in two years }(2012 \\
\text { and } 2013)\end{array}$ & B1ii, C2, C6 \\
\hline $\begin{array}{l}\text { Extension to } \\
\text { IBA Debeli rtič }\end{array}$ & $\begin{array}{l}\text { - GPS } \\
\text { telemetry } \\
\text { dataset } \\
\text { - large floating } \\
\text { groups } \\
\text { dataset } \\
\text { - bathymetry } \\
\text { layer }\end{array}$ & 155 ha & $\begin{array}{l}\operatorname{up}_{129} \text { to } 310^{3} \\
1299^{4}\end{array}$ & $\begin{array}{l}1 \% \text { population } \\
\text { threshold } \\
\text { exceeded in two } \\
\text { years ( } 2011 \text { and } \\
2014)\end{array}$ & B1ii, C2, C6 \\
\hline
\end{tabular}

Mean number of shags using the area in summer months over two years, estimated based on the extrapolation; mean number of shags using the area in peak non-breeding season, estimated based on the model M1.5; maximum number of shags observed within the same foraging group;

estimated number of shags using the marine IBA candidate $1 \mathrm{~A}$, identified based on the GPS telemetry data.

Table 14. Estimated numbers of the Mediterranean Shags Phalacrocorax aristotelis desmarestii in the Slovenian territorial sea and in the IBA Osrednji Tržaški zaliv (OTZ), based on the extrapolation from the ESAS dataset.

(1): Number of all floating shags, (2): number of floating shags without individuals associated with fishing boats. Results of the censuses from 22.6.2012 and 17.5.2013 were omitted due to unrepresentativeness of the sample. Censuses marked with asterisk were conducted within the peak non-breeding season.

\begin{tabular}{|c|c|c|c|c|c|c|c|c|c|}
\hline 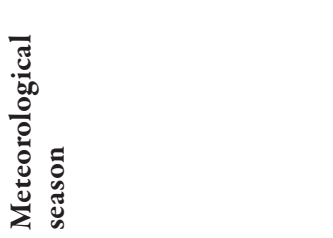 & 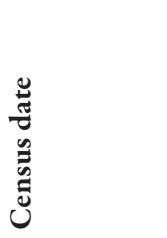 & 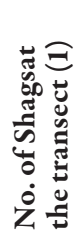 & 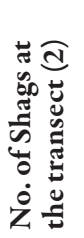 & 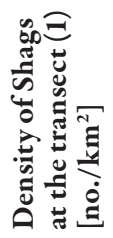 & 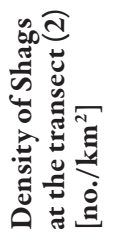 & 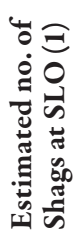 & 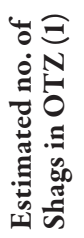 & 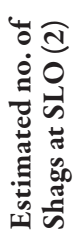 & 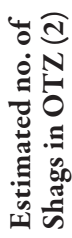 \\
\hline \multirow{3}{*}{ Summer } & $17.7 .2012^{*}$ & 131 & 131 & 2.7 & 2.7 & 572 & 349 & 572 & 349 \\
\hline & 7.8.2012* & 112 & 60 & 2.3 & 1.2 & 489 & 392 & 262 & 184 \\
\hline & $23.8 .2012^{*}$ & 145 & 95 & 3.0 & 1.9 & 633 & 425 & 415 & 225 \\
\hline \multirow{3}{*}{ Autumn } & 7.9.2012* & 50 & 50 & 1.0 & 1.0 & 218 & 110 & 218 & 110 \\
\hline & $18.10 .2012^{*}$ & 36 & 36 & 0.7 & 0.7 & 157 & 124 & 157 & 124 \\
\hline & 16.11.2012 & 21 & 13 & 0.4 & 0.3 & 92 & 26 & 57 & 26 \\
\hline \multirow{3}{*}{ Winter } & 19.12 .2012 & 11 & 9 & 0.2 & 0.2 & 48 & 20 & 39 & 20 \\
\hline & 23.1 .2013 & 7 & 7 & 0.1 & 0.1 & 31 & 4 & 31 & 4 \\
\hline & 19.2 .2013 & 2 & 2 & 0.0 & 0.0 & 9 & 0 & 9 & 0 \\
\hline \multirow{2}{*}{ Spring } & 22.3 .2013 & 1 & 1 & 0.0 & 0.0 & 4 & 0 & 4 & 0 \\
\hline & 19.4 .2013 & 19 & 19 & 0.4 & 0.4 & 83 & 44 & 83 & 44 \\
\hline \multirow{3}{*}{ Summer } & $19.6 .2013^{*}$ & 142 & 127 & 2.9 & 2.6 & 620 & 344 & 555 & 337 \\
\hline & $26.7 .2013^{*}$ & 215 & 167 & 4.4 & 3.4 & 939 & 458 & 729 & 458 \\
\hline & $23.8 .2013^{*}$ & 101 & 101 & 2.1 & 2.1 & 441 & 277 & 441 & 277 \\
\hline All year & & 71 & 58 & 1.4 & 1.2 & 310 & 184 & 255 & 154 \\
\hline Summer & & 141 & 114 & 2.9 & 2.3 & 616 & 374 & 496 & 305 \\
\hline Peak non-breeding season & & 117 & 96 & 2.4 & 2.0 & 509 & 310 & 419 & 258 \\
\hline
\end{tabular}


shags is established on high abundance and easy access of suitable prey species, especially the black goby Gobius niger. The species has been identified as the dominant prey of the Mediterranean Shags in the Gulf of Trieste in two recent studies (Cosolo et al. 2011, LIPEJ et al. 2016). The black goby is a common benthic fish species throughout the Gulf of Trieste (LIPEJ et al. 2016), however, its spatiotemporal dynamics within the Slovenian sea is not well known. Based on the existing data, it is not possible to conclude that the peak densities of the Mediterranean Shags, consistently found in off-shore areas within the scope of the systematic ESAS monitoring, reflect higher densities of prey in these areas, although this is a plausible hypothesis. Moreover, the distribution of shags at sea could also be affected by the level of disturbance but the effect of this factor was not considered in our study.

The IBA Osrednji Tržaški zaliv overlaps with the national B fishing zone (KLANJščEK et al.), regularly exploited by bottom and midwater otter trawlers, purse seiners and pelagic pair trawlers (MKGP 2011). All these fishing techniques use vessels defined in this study as large fishing boats. Groups of shags have been occasionally observed to follow the boats and forage on the discards (own unpublished data and B. Marčeta, personal communication). This suggests that higher abundances of shags in the off-shore areas could be the consequence of fishing activities in these areas. In fact, the presence of large fishing boats in a transect segment or in its close vicinity (i.e. $<500 \mathrm{~m}$ from the instant observation point) had a strong positive effect on the number of shags, as revealed by one of the selected models fit for the ESAS dataset in this study. Nevertheless, a comparison of both selected models revealed that the number of shags within the transect segment increases with increasing distance from the coast independently of the presence of fishing boats. Moreover, the occasional discards probably do not represent an essential source of food for the Mediterranean Shag, as they are relatively scarce in this area (MKGP 2011). We thus suggest that fishing activity is not an ultimate factor influencing the distribution of shags in the Slovenian sea, but it can cause temporary aggregations of the individuals that primarily visit the overlapping area to prey on the bottom dwelling prey species, predominantly the black goby.
The IBA Osrednji Tržaški zaliv was identified based on one primary data source, the spatial distribution of shags, as revealed by the ESAS monitoring. However, the results of GPS telemetry do not comply with these findings as they suggest that the shags' most important foraging areas are located along the coast. According to the recommendations by the marine IBA identification protocol (BIRDLIFE INTERNATIONAL 2010b), the GPS telemetry data, retrieved from more than 10 individuals, classifies as the primary data source, but we classified it as supplementary despite adequate number of tracked individuals. The reason for this lies in the fact that the sample of tracked shags was biased due to non-randomized catching. The majority of individuals were caught at one near-coast location, characterized as a resting spot used by the shags during their diurnal activities (i.e. between foraging episodes). As revealed by the results of this telemetry study, many shags tend to be faithful to their foraging areas, meaning that our sample was at least to some degree biased towards the locally-foraging population and thus not representative for the entire roosting population. To ensure random sampling, the majority of shags should be caught at their communal roostsites. However, these individuals were extremely hard to catch as they tended to avoid the floating rafts and buoys with mounted traps, placed in the environment with abundant alternative traditional roosting structures, i.e. the shellfish farm buoys. Another possible source of bias could be the difference in total diving time when shags are foraging in shallow coastal waters or foraging in deep off-shore waters, which would affect the frequency of successfully fixed GPS locations. However, the total diving time of individuals was not assessed in this study.

Nevertherless, the GPS telemetry and landbased census of large floating groups importantly supplement the ESAS censuses that tend to overlook the shags closely associated with the sea-shore. As part of the maritime traffic rules, the ESAS census boat was not allowed to travel with required speed closer than $400 \mathrm{~m}$ from the shoreline, missing out at least the innermost $100 \mathrm{~m}$ coastal belt where most communal foraging occurs. Although the supplementary datasets do not provide adequate data to evaluate the entire Slovenian coastal belt, 
they do provide adequate information to identify an important foraging area extending from the existing marine IBA Debeli rtič along several kilometres of the coast. The importance of the site for the socially foraging shags is supported also with the findings of their diet analysis that revealed disproportionally high frequencies of sand-smelts in the diet of individuals roosting at the Debeli rtič roost-site (LIPEJ \& MAVRIČ 2013, LIPEJ et al. 2016). However, the rest of the innermost coastal belt should be further evaluated in terms of its importance for foraging shags through systematic land-based monitoring from several spots at the coast and through systematic monitoring of innermost coastal belt by slow-speed travelling boat.

The standard IBA criteria used for site justification require two conditions to be met: (1) regular use, and (2) threshold number of individuals utilizing the site. For the purpose of marine IBA justification, the regularly used areas were defined as areas visited by birds from more than one site or during different periods (i.e. seasons or years) (BIRDLife INTERNATIONAL 2010b).

Regular use of the IBA Osrednji Tržaški zaliv was demonstrated by repeated systematic censuses over the period of 13 months and two non-breeding seasons in 2012 and 2013. It was demonstrated that in both years the number of shags using the area exceeded 300 individuals in several months and that the average summer number over both years was above 300 individuals. It is of utmost importance to stress that these calculations do not take into account the turnover, i.e. the phenomenon that more birds are actually using the site over a period of time than the number of individuals recorded at any given moment during the census. The turnover rates for the foraging Mediterranean Shags in this study were not assessed and thus the true number of individuals using the IBA within one season cannot be estimated, but it could be considerably higher than the estimated numbers. This is very important to consider in the attempts to compare these estimated numbers against the size of the roosting population, acquired by total counts of static individuals within the roost-site monitoring. Moreover, the first few censuses implemented in 2012 (from July to September) were not conducted in the optimal time of the day, as their starting time was too early. Based on the data from a few all-day monitorings of the communal roots-sites, conducted after the onset of ESAS monitoring (Bordjan et al. 2013, Pavletič 2013, Rozman 2012), the optimal time for at-sea census in the peak non-breeding season is between $10 \mathrm{a} . \mathrm{m}$. and $4 \mathrm{p} . \mathrm{m}$. It was estimated that $48-70 \%$ shags were staying at the roost-sites during the first hour of the censuses that started around 8 a.m., $31-43 \%$ in the first hour of censuses starting around 9 a.m. and only $13-28 \%$ in the first hour of censuses started between 10-11 a.m. (own unpublished data). Based on these data we conclude that the estimated number of shags censuses between July and September 2012 does not reflect the peak diurnal numbers of shags in the IBA Osrednji Tržaški zaliv.

The estimated number of shags in the IBA Osrednji Tržaški zaliv and even in the entire target area was well below 300 individuals in two of the eight censuses during peak non-breeding season (September and October 2012), although the number of roosting population was at its highest level. These low estimated numbers of shags at sea coincide with the autumn period when the shags frequently formed large groups and foraged on schools of small pelagic fish in the shallow coastal waters. These groups were often formed of 100 or more individuals, and nine such cases were reported in September and October 2012 (max. 230 individuals in one group) only in random observations. Since the large groups foraging in the innermost coastal belt might have been overlooked from the ESAS census boat, this seasonal phenomenon could explain the lower numbers of shags in the autumn peak non-breeding season months, estimated based on the ESAS dataset.

The IBA Debeli rtič has been estimated to hold about 800 roosting individuals in the 2006-2011 period (DENAC et al. 2011). In this study, however, a maximum of 532 and 610 individuals were registered during the peak non-breeding seasons in 2012 and 2013, respectively. The roost-site itself meets IBA criteria, but the extension can also be justified as an important foraging area. The shags tend to form large foraging groups around this roost-site, diving after schools of small pelagic fish along the coast outside the original IBA borders. Two groups of 300 and 310 individuals were observed in the area in two different years, proving that the numerical threshold has been met without 
even considering the turnover rates. Regular use of the extension to the existing IBA was demonstrated by both types of data used for its delineation. The large groups of 130 or more individuals were observed in the area in four different years and the area was visited by shags from two different roostsites as revealed by the GPS telemetry data.

Least but not last, the results of this study should be viewed on the spatial scale of the entire Gulf of Trieste. The non-breeding population of the Mediterranean Shags within this region cannot be partitioned to national fragments. Although the identification of marine IBAs for the Mediterranean Shag was limited to the Slovenian territorial sea within the scope of the SIMARINE-NATURA (LIFE10NAT/SI/141) project, the data collected in this study as well as previous knowledge about the distribution of Mediterranean Shags in the region call for the identification of complementary sites within the Italian waters or transboundary sites spanning across the political borders.

\section{Povzetek}

Omrežje IBA redno posodabljamo na osnovi novih podatkov in njihove boljše kakovosti. V Sloveniji smo morska območja IBA v preteklosti opredelili v treh fazah, vendar je bil sredozemski vranjek vključen kot kvalifikacijska vrsta le v zadnji fazi leta 2011. Toda ker so bila območja omejena na njegova obalna prenočišča, niso zadostovala za pokrivanje prehranjevalnih območij te vrste. Da bi zapolnili to vrzel $\mathrm{v}$ slovenskem teritorialnem morju, smo $\mathrm{v}$ okviru projekta SIMARINENATURA (LIFE10NAT/SI/141) v obdobju 2011-2015 opredelili nova morska območja IBA za sredozemskega vranjeka, in sicer po standardizirani metodologiji naravovarstvene organizacije BirdLife International za opredelitev morskih območij IBA. Podatki o razširjenosti in velikosti populacij sredozemskega vranjeka so bili zbrani z naslednjimi terenskimi metodami: (1) mesečnim monitoringom na skupnih obalnih prenočiščih, (2) mesečnim monitoringom na morju po standardizirani metodi ESAS, (3) z GPS-telemetrijo, in (4) nesistematičnim štetjem obalnih skupin plavajočih osebkov. $\mathrm{Na}$ osnovi teh podatkov smo opredelili eno novo območje, IBA Osrednji Tržaški zaliv, in razširitev že obstoječega IBA Debeli rtič, ki pokrivata 8218 oziroma 155 ha. Novi območji tako pokrivata 39,2 \% slovenskega teritorialnega morja.

\section{Acknowledgements}

This research was done as part of the project SIMARINE-NATURA (LIFE10NAT/SI/141) project co-financed by LIFE, the EU's financial instrument for the Environment. Other co-financers were: Ministry of the Environment and Spatial Planning, City Municipality of Koper, Municipality of Izola and Municipality of Piran.

I am especially grateful to many who took part or otherwise helped in this study either as professionals or volunteers. This research could not be accomplished without their participation. These were (in alphabetical order): Andrej Bibič, Dr Dejan Bordjan, Igor Brajnik, Bruna Campos, Dr Damijan Denac, Katarina Denac, Dr Maria Dias, Ana Dolenc, Dare Fekonja, Jernej Figelj, Dr Irena Fonda, Jakob Fric, Tilen Genov, MSc, Pedro Geraldes, Dr Jonathan Green, Dr Mateja Grego, Eva Horvat, Lech Iliszko, Kaja Jensterle, Martina Kačičnik Jančar, MSc, Luka Kastelic, Mirko Kastelic, Dr Primož Kmecl, Brina Knez, Neža Kocjan, Dr Ben Lascelles, Julijana Lebez-Lozej, MSc, Bojana Lipej, Dr Lovrenc Lipej, Metka Lotrič, Bojan Marčeta, Dr Borut Mavrič, Andrej Medved, MSc, Ana Meirinho, Nace Mihelič, Tomaž Mihelič, Dr Roberto Odorico, Polona Pagon, Miša Pavletič, Dr Polona Pengal, Nevenka Pfajfar, Patrik Pucer, Anja Pitamic, Dejan Putrle, Bia Rakar, Rok Rozman, Borut Rubinić, Dr Stefano Sponza, Domen Stanič, Dr Boštjan Surina, Nataša Šalaja, MSc, Bojan Škerjanc, Iztok Škornik, Tanja Šumrada, Marguerite Tarzia, Dr Davorin Tome, Robert Turk, MSc, Paolo Utmar, Duša Vadnjal, Barbara Vidmar, Dr Al Vrezec, Eva Vukelič. A big thank you also to anonymous referees and the editor for their valuable comments to the manuscript.

Last but not least, I am sincerely grateful also to many unnamed for their kind support during the course of the project. 


\section{References}

BAZIN N., Imbert M. (2012): Mediterranean Shag Phalacrocorax aristotelis desmarestii. Updated state of knowledge and conservation of the nesting populations of the Mediterranean Small Islands. Initiative PIM.

Aguilar, J. S., Fernández, G. (2002): Species Action Plan for the Mediterranean Shag (Phalacrocorax aristotelis desmarestii). Final draft. - BirdLife International, Strasbourg.

BirdLife InTERnATIONAL (2004): Birds in Europe: population estimates, trends and conservation status. BirdLife Conservation Series No. 12. - BirdLife International, Cambridge.

BIRDLIFE INTERNATIONAL (2010a): Marine IBAs in the European Union. Version 1.1. - BirdLife International, Brussels.

BirdLife InTERnATIONAL (2010b): Marine Important Bird Areas toolkit: standardised techniques for identifying priority sites for the conservation of seabirds at sea. - BirdLife International, Cambridge.

BIRDLIFE INTERNATIONAL (2010c): Marine Important Bird Areas: priority sites for the conservation of biodiversity. - BirdLife International, Cambridge.

BIRDLIFE INTERNATIONAL (2013): Methods for identifying marine IBAs using seabird tracking data. Preliminary version - 23rd Dec 2013.

BirdLife InTERnATIONAL (2014): Marine Natura 2000 Progress Assessment. - BirdLife International, Cambridge.

Bordjan D., Gamser M., Kozina A., Novak J., DENAC M. (2013): Roost-site characteristics of the Mediterranean Shag Phalacrocorax aristotelis desmarestii along the Slovenian coast. - Acrocephalus $34(156 / 157): 5-11$.

BožIČ L. (2003): Mednarodno pomembna območja za ptice v Sloveniji 2. Predlogi posebnih zaščitenih območij (SPA) v Sloveniji. Monografija DOPPS št. 2. - DOPPS, Ljubljana.

Burnham K. P., Anderson D. R. (2002): Model Selection and Multimodel Inference. A Practical Information-Theoretic Approach. - Springer, New York.

Camphuysen K. C. J., Garthe S. (2004): Recording foraging seabirds at sea. Standardised recording and coding of foraging behaviour and multi-species foraging associations. - Atlantic Seabirds 6 (1): 1-32.

Cosolo M., Privileggi N., Cimador B., Sponza $S$. (2011): Dietary changes of Mediterranean Shags Phalacrocorax aristotelis desmarestii between the breeding and post-breeding seasons in the upper Adriatic Sea. - Bird Study 58 (4): 461-472.

Denac K., Mihelič T., Božič L., KMecl P., Jančar T., Figelj J., Rubinić B. (2011): Strokovni predlog za revizijo posebnih območij varstva (SPA) z uporabo najnovejših kriterijev za določitev mednarodno pomembnih območij za ptice. Končno poročilo (dopolnjena verzija). - DOPPS, Ljubljana.

KLANJŠČEK, M., ZdeŠAR KadUnC, Š., KaRniČNiK, I., Radovan, D. (2015): Ažuriranje kart rab na morju. Kartografska in geoinformacijska podpora za prikaz stanja prostora za območje slovenskega dela Jadranskega morja. Končno poročilo - IZVLECEK. - Geodetski inštitut Slovenije, Ljubljana.

Koce U., Lipej B. (2016): Varstvo sredozemskega vranjeka in drugih morskih ptic $\mathrm{v}$ slovenskem morju. Priročnik za uporabnike in upravljavce morskega prostora.- DOPPS, Ljubljana.

Lipej L., Mavrič B. (2013): Prehranjevalna ekologija sredozemskega vranjeka (Phalacrocorax aristotelis desmarestii) v slovenskem delu Jadranskega morja. Poročilo za projekt: SIMARINE-NATURA (LIFE10NAT/SI/141) - Preparatory inventory and activities for the designation of marine IBAs and SPAs for Phalacrocorax aristotelis desmarestii in Slovenia. - Shoreline, Trieste.

Lipej L., Mavrič B., Odorico R., Koce U. (2016): The diet of the Mediterranean Shag Phalacrocorax aristotelis desmarestii roosting along the Slovenian coast. - Acrocephalus 37: 151-158.

MKGP (2011): Program upravljanja z morskim ribištvom v vodah pod suverenostjo ali jurisdikcijo Republike Slovenije.

NeLson J. B. (2005): Pelicans, Cormorants and their relatives, The Pelecaniformes. Bird Families of the World. - Oxford University Press, New York.

PAVLETIČ M. (2013): Monitoring sredozemskih vranjekov (Phalacrocorax aristotelis desmarestii). Poročilo terenskega dela pri predmetu Ornitologija. - Univerza v Ljubljani, Biotehniška fakulteta, Ljubljana.

Peterlin M., Gabrijelčič E., Orlando Bonaca M., Lipej L., Malej A., Francé J., Čermelj B., Bajt O., Kovač N., Mavrič B., TuRK V., MoZEtičP., RamŠAK A., Kogovšek T., ŠišKo M., Flander Putrle V., Grego M., Tinta T., Petelin B., Vodopivec M., Jeromel M., Martinčič U., Malačič V., MarčEta B., Pengal P., Strojan, I. (2013): Začetna presoja morskih voda v pristojnosti Republike Slovenije. Bistvene lastnosti in značilnosti morskih voda. Inštitut za vode Republike Slovenije, Ljubljana.

POlaK S. (2000): Mednarodno pomembna območja za ptice v Sloveniji. Monografija DOPPS št. 1. DOPPS, Ljubljana.

R Development Core Team (2018): R: A language and environment for statistical computing. - $\mathrm{R}$ Foundation for Statistical Computing, Wien.

Rozman R. (2012): Dnevna dinamika številčnosti sredozemskih vranjekov (Phalacrocorax aristotelis desmarestii) na prenočiščih Debeli rtič in Strunjan. Individualna naloga pri predmetu Terensko delo 
iz botanike in zoologije. - Univerza v Ljubljani, Oddelek za biologijo BF, Ljubljana.

Sponza S., Cimador B., Cosolo M., Ferrero E. (2010): Diving costs and benefits during postbreeding movements of the Mediterranean shag in the North Adriatic Sea. - Marine Biology 157 (6): 1203-1213.

Sponza S., Cosolo M., Kralj, J. (2013): Migration patterns of the Mediterranean Shag Phalacrocorax aristotelis desmarestii (Aves: Pelecaniformes) within the northern Adriatic Sea. - Italian Journal of Zoology 2013: 1-12.

Š́ornik I., Utmar P., Kravos K., Candotto S., CRnković, R. (2011): Important post-breeding roosting area of Mediterranean Shag Phalacorax aristotelis desmarestii in Gulf of Trieste (N Adriatic). - Medmaravis, Alghero.

Venables W. N., Ripley B. D. (2002): Modern Applied Statistics with S. - Springer, New York.

VREZEC A. (2006a): Marine and coastal birds of Slovenia: status, population size and conservation of Mediterranean action plan species. - RAC/SPA, Tunis Vilanova i la Geltrú.

VREzeC A. (2006b): Tržaški zaliv - mednarodno morsko območje IBA / SPA? - Acrocephalus 27 (130/131): 117-129.

WETLANDS INTERNATIONAL (2004): Waterbird Population Estimates, 4th edition. - Wetlands International, Wageningen.

Wood S. N. (2004): Stable and efficient multiple smoothing parameter estimation for generalized additive models. - Journal of the American Statistical Association 99: 673-686.

Zuur A. F., Ieno E. N., Walker N. J., Saveliev A. A., Smith G. M. (2009): Mixed Effects Models and Extensions in Ecology with R. Statistics for Biology and Health. - Springer, New York.

Prispelo / Arrived: 12. 12.2018

Sprejeto / Accepted: 27. 2. 2019 